\title{
KECEKAPAN PENGURUSAN KEWANGAN DAN AGIHAN ZAKAT: KAJIAN DI MAJLIS UGAMA ISLAM SABAH (MUIS)
}

\section{Efficiency of Financial and Zakāh Distribution \\ Management: A Study at Sabah Islamic Religious Council (MUIS)}

\author{
Pg Mohd Faezul Fikri Ag Omar ${ }^{1}$ \\ Hairunnizam Wahid ${ }^{2}$ \\ Mohd Ali Mohd Nor ${ }^{3}$
}

\begin{abstract}
A strong financial performance for Majlis Agama Islam Negeri is crucial for determining the efficacy of the institution's operations, particularly in zakāh collection and distribution. An efficient financial management over zakāh distribution is important for eradicating poverty and ensuring future development of a society. On the other hand, the inefficiency of zakah distribution by the zakāh institutions in Malaysia could negatively affect Muslims towards paying zakāh subsequently the performance of said institutions. As reported in previous research, it has been observed
\end{abstract}

1 Master Candidate, Faculty of Economics and Management, The National University of Malaysia, Bangi, pengiranfaezul@gmail.com

2 Senior Lecturer, School of Economics, Faculty of Economics and Management, The National University of Malaysia, Bangi, hairun@ukm.edu.my

3 Senior Lecturer, School of Economics, Faculty of Economics and Management, The National University of Malaysia, Bangi, ali@ukm.edu.my 
that an excess of zakāh funds remain undistributed every year to eight categories of asnaf. As such, this study examines the efficacy of MUIS financial management as well as of zakāh distribution by Pusat Zakat Sabah (PZS-MUIS); using the secondary data collected from MUIS financial report from 2000 to 2013. Several cash flow ratios were used as a proxy for financial performance, as well as the data for zakāh distribution. The results of ratio analyses indicate that there have been significant enhancements in financial and zakāh distribution during by both MUIS and PZS-MUIS during the period of this study, even though the efficiency scores obtained are inconsistent. This study suggests that both MUIS and PZS-MUIS have to maintain and enhance their performance for the future. This study shows that both financial and zakāh distribution management performance need to be achieved simultaneously for optimal zakāh distribution and offers several recommendations.

Keywords: Sabah Islamic Religious Council (MUIS), Pusat Zakat Sabah (PZS-MUIS), efficiency financial management, zakāh distribution management

\section{PENGENALAN}

Zakat sebagai salah satu komponen utama dalam sistem ekonomi Islam berfungsi secara efektif dalam menangani kemiskinan dan menyumbang dalam pembangunan ekonomi sesebuah negara Islam. Sejarah Islam telah membuktikan bahawa kecekapan dalam mengurus dan mengagihkan dana zakat menjadi punca kepada kemakmuran negara sehingga kemiskinan sifar boleh dicapai dan sosioekonomi mahupun kualiti hidup masyarakat dapat ditingkatkan seperti pada zaman Khalifah 'Umar al-Khatțab. Dalam konteks Malaysia sebagai sebuah negara Islam yang bakal mencapai status negara maju dan berpendapatan tinggi menjelang 2020, pengurusan dana zakat yang efisien memainkan peranan yang sangat penting bagi mencapai matlamat tersebut terutama dalam menangani kemiskinan dan meningkatkan pembangunan ekonomi dan nilai modal insan. Setiap negeri di Malaysia pula mempunyai sistem pentadbiran dan pengurusan zakat tersendiri kerana ia terletak di bawah 
bidang kuasa negeri seperti yang termaktub dalam Perlembagaan Persekutuan Malaysia. $^{4}$

Bagi negeri Sabah pula, perkembangan pentadbiran dan pengurusan zakat bermula pada awal penubuhan Majlis Ugama Islam Sabah (MUIS) sekitar awal tahun 1970-an. ${ }^{5}$ Terdapat sebuah entiti utama di bawah MUIS pada ketika itu iaitu unit Baitulmal yang bertanggungjawab mengurus hal ehwal pungutan dan agihan zakat di samping sumber-sumber am baitulmal yang lain di negeri ini. Namun, sejak tahun 1994 unit tersebut telah dinaikkan taraf menjadi Bahagian Baitulmal dan Zakat kerana bebanan tugas yang semakin meningkat. Pada November 2004, bahagian tersebut telah dimansuhkan dan diganti dengan Bahagian Zakat dan Fitrah sejajar dan tertakluk di bawah peruntukan dalam Enakmen Zakat dan Fitrah Negeri Sabah (No. 6 Tahun 1993), berikutan penubuhan Perbadanan Baitulmal Negeri Sabah. Penubuhan Pusat Zakat Sabah (MUIS) pula merupakan cetusan idea Yang Amat Berhormat Datuk Seri Panglima Haji Musa bin Haji Aman, merangkap Ketua Menteri Sabah. Idea ini tercetus dalam memastikan pemerkasaan institusi pengurusan zakat sebagai wadah untuk meninggikan syiar Islam dan memangkin martabat umat Islam menerusi pengurusan profesional dan berimejkan korporat sebagaimana yang telah terlaksana di beberapa institusi zakat negeri lain di Malaysia.

Sebuah Jawatankuasa Khas Pengurusan Zakat Jabatan Ketua Menteri ditubuhkan bertujuan membuat kajian dan menentukan halatuju pengurusan institusi zakat di Sabah. Jawatankuasa tersebut telah mengadakan beberapa siri mesyuarat di samping lawatan kerja ke Pusat Pungutan Zakat (PPZ) Majlis Agama Islam Wilayah Persekutuan, Lembaga Zakat Selangor (LZS) Majlis Agama Islam Selangor, Pusat Zakat Melaka (PZM) Majlis Agama Islam Melaka dan Institusi Kajian Zakat Malaysia (IKAZ). Sebelum membuat ketetapan, jawatankuasa tersebut turut mengambil kira beberapa pandangan dan nasihat termasuk daripada Jabatan Wakaf, Zakat dan Haji Jabatan Perdana Menteri, Sekolah Perniagaan dan Ekonomi Universiti Malaysia Sabah (UMS) dan individu-individu yang berpengalaman serta terlibat secara langsung dalam pengurusan zakat seperti Tuan Haji Ismail Saad dan Prof $\mathrm{Dr} \mathrm{Hj}$ Mujaini Tarimin, Felo Kanan Institut Pengajian dan Kefahaman Islam UiTM Shah Alam. Maka dalam usaha meningkatkan keberkesanan dan kecekapan

4 Hairunnizam Wahid, Sanep Ahmad, Mohd Ali Mohd Nor \& Maryam Abd Rashid, 'Prestasi Kecekapan Pengurusan Kewangan dan Pengurusan Agihan Zakat: Perbandingan antara Majlis Agama Islam Negeri', Isu Kontemporari Agihan Zakat di Malaysia, ed. Nor Aini Ali et al. (Kuala Lumpur: Majlis Agama Islam Wilayah Persekutuan (MAIWP), 2015): 21-35.

5 Pusat Zakat Sabah, 'Sejarah Penubuhan Pusat Zakat Sabah,' laman sesawang Pusat Zakat Sabah, www.zakat.sabah.gov.my, dicapai pada 25 Mac 2016. 
pengurusan Bahagian Zakat dan Fitrah di Sabah, pada April 2007 Bahagian Zakat dan Fitrah diberikan nafas baharu dan dikenali sebagai Pusat Zakat Sabah (PZS-MUIS) tanpa mengubah strukturnya sebagai salah satu bahagian di bawah pentadbiran Majlis Ugama Islam Sabah (MUIS). Secara tuntasnya, MUIS masih berkuasa dalam perihal pungutan dan agihan zakat dan fitrah namun tanggungjawab tersebut dilaksanakan melalui Pusat Zakat Sabah tertakluk kepada peruntukan di bawah Enakmen Zakat dan Fitrah $1993 .{ }^{6}$

Dalam agenda membasmi kemiskinan dan meningkatkan pembangunan sosioekonomi dan taraf hidup masyarakat di samping memperkasa institusi zakat di Sabah, kecekapan pengurusan melibatkan kutipan dan agihan dana zakat adalah dituntut. Menurut kajian, terdapat rungutan daripada masyarakat setempat tentang pelaksanaan pungutan dan agihan zakat melibatkan sebuah daerah di Sabah. Ini dikejutkan lagi dengan keengganan dalam membayar zakat oleh masyarakat tersebut yang turut diakibatkan oleh kesedaran membayar zakat dalam kalangan masyarakat yang rendah. ${ }^{7}$ Kajian lain turut mendapati pungutan zakat di Sabah secara relatifnya masih rendah berbanding Sarawak dan Semenanjung, malah pungutan zakat di Sabah masih kurang berbanding pungutan cukai negeri dan jumlah penduduk Islam. ${ }^{8}$ Situasi ini pasti menjejaskan reputasi dan keyakinan kepada Majlis Agama Islam dan institusi zakat terutama melibatkan kecekapan dan ketelusan dalam hal melibatkan zakat. Objektif utama pembangunan yang ingin dicapai oleh kerajaan negeri mungkin terbantut disebabkan kelemahan ini. Kerajaan Negeri Sabah menerusi halatuju pembangunan dan kemajuan negeri Sabah atau "Halatuju" jelas menggariskan agenda pembangunan sosial meliputi usaha membasmi kemiskinan dan meningkatkan sosioekonomi dan kualiti kehidupan rakyat. Ini termasuk agenda pembangunan sumber manusia dan meningkatkan kebolehan dan kecekapan sistem penyampaian kerajaan yang dititikberatkan dalam pelan tersebut. ${ }^{9}$ Walaupun secara teorinya, zakat mampu menjadi ejen membasmi kemiskinan dan pembangunan sosioekonomi masyarakat, namun ia perlu dibuktikan dalam realiti kehidupan. Justeru, bagi memastikan objektif tersebut tercapai, pelaksanaan agihan dana zakat yang efisien dan telus harus dirangka

\footnotetext{
$6 \quad$ Enakmen Majlis Ugama Islam Negeri Sabah (No.5 Tahun 2004).

7 Ahmad Hidayat Buang \& Saidatul Badrul Mohd Said, 'Pentadbiran Zakat dan Kesedaran Masyarakat Islam Membayar Zakat di Daerah Kota Belud Sabah', Sains Humanika, 2/1 (2014): 125-134.

8 Dayangku Aslinah Abd. Rahim, 'Zakat Potential in Sabah: Issues and Challenges' ( $5^{\text {th }}$ Islamic Economics System Conference (iECONS), Berjaya Times Square Hotel, Kuala Lumpur, 2013), 991-997.

9 Halatuju Pembangunan dan Kemajuan Negeri Sabah atau 'Halatuju', http// www. sabah.gov.my/cm/halatuju.php/, dicapai pada 20 Mac 2016.
} 
selari dengan objektif sesebuah negeri agar tidak wujud kepincangan malah menstabilkan lagi pembangunan ekonomi.

Secara amnya, terdapat banyak pandangan berkaitan aspek pengagihan dana zakat kepada golongan asnaf. Namun, bagi konteks Malaysia, kerajaan telah menetapkan negara ini tertakluk kepada pegangan Mazhab Shāfi '⿳亠 d dari segi Syariah. Terdapat lapan golongan yang berhak menerima zakat seperti disebutkan dalam al-Quran, iaitu al-fuqarā' (golongan fakir), al-masākīn (golongan miskin), amil, mualaf, al-riqāb (hamba), al-ghārimīn (golongan berhutang), fi sabìlillah (golongan berjuang di jalan Allah) dan ibn sabìl (golongan bermusafir):

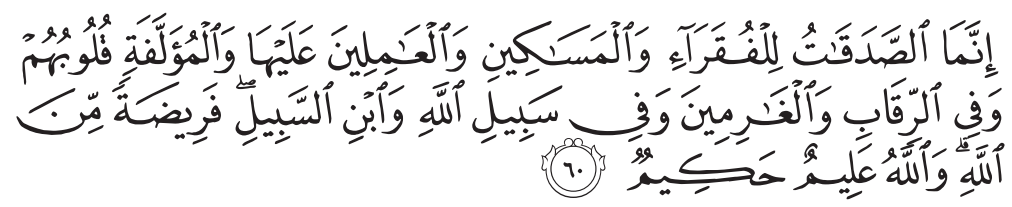

"Sesungguhnya sedekah-sedekah (zakat) itu hanyalah untuk orang-orang fakir, dan orang-orang miskin dan amil-amil yang mengurusnya dan orang-orang mualaf yang dijinakkan hatinya dan untuk hamba-hamba yang hendak memerdekakan dirinya, dan orang-orang yang berhutang dan untuk (dibelanjakan pada) jalan Allah, dan orang-orang musafir (yang keputusan) dalam perjalanan. (Ketetapan hukum yang demikian itu ialah) sebagai satu ketetapan (yang datangnya) dari Allah. Dan (ingatlah) Allah Maha Mengetahui, lagi Maha Bijaksana."

(Surah al-Tawbah, 9: 60)

Menurut mazhab Imam Shāfi' $\overline{1}$, zakat juga memadai diagihkan kepada sekurang-kurangnya tiga golongan sahaja yang mana golongan ketiga adalah amil. Secara umumnya, terdapat empat golongan yang perlu diutamakan terlebih dahulu dalam pengagihan dana zakat iaitu al-fuqara ' (golongan fakir), al-masākīn (golongan miskin), al-ghärimīn (golongan berhutang), dan ibn sabïl (golongan bermusafir). ${ }^{10}$ Justeru, amil akan mengambil tempat ketiga selepas asnaf fakir dan miskin berdasarkan hujah sekurang-kurangnya agihan dilaksanakan kepada tiga golongan asnaf. Berlandaskan keutamaan ini, bagi mencapai keadilan yang optimum, institusi zakat perlu memastikan dana zakat

10 Mohamad Uda Kasim, Zakat: Teori, Kutipan dan Agihan (Kuala Lumpur: Utusan Publications \& Distributors Sdn Bhd, 2013), 202-203. 
diagihkan terlebih dahulu kepada kelima-lima asnaf di atas sebelum asnaf selebihnya yang dinyatakan dalam al-Quran. ${ }^{11}$

Rasional kajian dilakukan adalah menguji kecekapan dalam pengurusan kewangan majlis agama dan institusi zakat dalam mengagihkan dana zakat, kerana sekiranya berlaku ketidakcekapan, maka akan mewujudkan persepsi yang kurang baik terhadap kedua-duanya. Kurangnya kajian mengenai prestasi pengurusan kewangan Majlis Agama Islam Negeri di Malaysia terutamanya di negeri Sabah sendiri dan hubungannya dengan prestasi agihan zakat dalam bentuk agihan kewangan dan bukan kewangan menjadi salah satu objektif kajian ini dilakukan. Keunikan Sabah sebagai sebuah negeri yang mempunyai pelbagai latar kaum, bangsa, agama dan kepercayaan yang kompleks dan berbeza berbanding negeri-negeri lain mewujudkan suatu cabaran kepada institusi agama dan pengurusan pusat zakat negeri dalam mentadbir dan memastikan ketercapaian objektif dan kelancaran operasi zakat turut menjadi objektif kajian dijalankan terutama perkembangan pengurusan zakat berkaitan mualaf serta pembangunan taraf sosioekonomi umat Islam yang berlainan bangsa dan kaum. Kajian menjangkakan terdapat hubungan yang signifikan antara kedua-dua prestasi tersebut. Hasil kajian ini diharap dapat menyumbang kepada penambahan literatur kajian mengenai zakat di Sabah yang kurang dikaji sebelumnya seterusnya meningkatkan kredibiliti MUIS dan PZS-MUIS dan keyakinan masyarakat terhadap institusi tersebut pada masa akan datang secara keseluruhannya.

\section{KAJIAN LEPAS}

Aspek kecekapan pengurusan kewangan adalah sangat penting dalam operasi sesebuah firma, syarikat atau jabatan. Analisis kewangan merujuk kepada pemilihan, penilaian dan tafsiran data kewangan, bersama-sama dengan data lain yang berkaitan dalam membantu proses pembuatan keputusan bagi pelaburan dan kewangan. Analisis kewangan boleh digunakan secara dalaman untuk menilai isu-isu seperti prestasi pekerja, kecekapan operasi dan dasar-dasar kredit, dan secara luaran untuk menilai potensi pelaburan dan kredit kepercayaan peminjam. ${ }^{12}$ Namun, kebanyakan kajian terdahulu hanya

11 Hairunnizam Wahid, Sanep Ahmad, Mohd Ali Mohd Nor \& Maryam Abd Rashid, 'Prestasi Kecekapan Pengurusan Kewangan dan Pengurusan Agihan Zakat: Perbandingan antara Majlis Agama Islam Negeri', 21-35.

12 Faiz Mat Isa, Hairunnizam Wahid \& Sanep Ahmad, 'Pengukuran Prestasi Menggunakan Nisbah Aliran Tunai dan Nisbah Tradisi: Perbandingan di Antara Majlis Agama Islam Selangor dan Majlis Agama Islam dan Adat Melayu Perak,' Proceeding International Conference Muamalat, Economic \& Islamic Finance (Bangi: Institut Latihan Islam Malaysia (ILIM), 2014), 310-325. 
memfokuskan kepada analisis perjalanan kewangan bagi perniagaan sektor swasta dan organisasi. Hanya pada akhir kurun ke-18 dan awal kurun ke-19, beberapa negara maju mula mengalihkan perhatian ke arah reformasi sektor awam melalui pelbagai inisiatif reformasi pengurusan kewangan sektor awam. Antara tujuan utama perubahan tersebut adalah wujud keperluan untuk cekap, efisien, efektif dan ekonomi yang memfokus kepada pengurusan operasi dan kewangan entiti sektor awam. ${ }^{13}$ Faktor ' $3 E$ ' iaitu ekonomi, efektif, dan esifien perlu dijadikan pengukur prestasi dalam sektor awam. ${ }^{14}$ Suatu kajian yang dijalankan turut membincangkan kepentingan dan kelebihan penggunaan kaedah nisbah tunai sebagai analisis kewangan. Kajian tersebut mendapati analisis nisbah kewangan adalah alat utama bagi diagnosis kewangan dan telah digunakan sejak abad ke-19 dan hanya pada 1991, kajian nisbah aliran tunai digunakan oleh penganalisis setelah dua tahun kemasukan penyata aliran tunai dalam laporan tahunan. ${ }^{15}$ Dalam menentukan keberkesanan dan tahap daya saing di pasaran, analisis aliran tunai dianggap lebih berkesan kerana ia lebih dinamik. ${ }^{16}$ Memandangkan Majlis Agama Islam Negeri merupakan sebuah entiti awam dan mempunyai kedudukan penting bagi masyarakat Islam, maka perlu bagi MAIN memastikan kedudukan kewangan berada pada tahap terbaik dan lebih berdaya saing agar kelancaran operasi terutamanya dalam mengutip dan mengagihkan zakat dicapai.

Kecekapan pengurusan kewangan MAIN dan prestasi kutipan dan agihan zakat serta hubungan antara kedua-duanya turut dibincangkan dalam kajian ini. Kajian berpendapat aspek kecekapan dalam kutipan dan agihan zakat merupakan perkara yang penting bagi institusi zakat malah masyarakat Islam seluruhnya. Dana zakat mampu memberi impak dalam pembasmian kemiskinan masyarakat dan pembangunan ekonomi negara sekiranya aspek

13 Monir \& Wahyu, 'Public Sector Financial Management Reform: A Case Study of Local Government Agencies in Indonesia,' Australasian Accounting, Business and Finance Journal, 7/4 (2013): 97-117.

14 Eza Ellany Abdul Lateff, Mohd Rizal Palil \& Mohamat Sabri Hassan, 'Prestasi Kecekapan Agihan Kewangan dan Bukan Kewangan dalam Kalangan Institusi Zakat di Malaysia,' Jurnal Ekonomi Malaysia, 48/2 (2014): 51-60.

15 Faiz Mat Isa, Hairunnizam Wahid \& Sanep Ahmad, 'Pengukuran Prestasi Menggunakan Nisbah Aliran Tunai dan Nisbah Tradisi: Perbandingan di Antara Majlis Agama Islam Selangor dan Majlis Agama Islam dan Adat Melayu Perak' 310-325.

16 Maxwell Samuel Amuzu, 'Cash Flow Ratio As A Measure of Performance of Listed Companies in Emerging Economies: The Ghana Example' (St. Clements University, Turks and Caicos Islands Dissertation, 2014). 
pengagihan zakat dititikberatkan. ${ }^{17}$ Agihan dana zakat juga memberi impak yang signifikan terhadap kualiti taraf hidup golongan asnaf yang turut dipengaruhi oleh kepuasan asnaf terhadap agihan zakat. ${ }^{18}$ Justeru, penerimaan masyarakat terhadap kecekapan dan keadilan dalam pengurusan dana zakat oleh institusi zakat sangat kritikal untuk dibincangkan. Ini kerana keadaan ini boleh mempengaruhi prestasi kutipan dan agihan zakat secara jangka panjang. Isu keyakinan masyarakat Islam yang rendah terhadap institusi zakat dan tadbir urus zakat yang tidak telus didakwa menjadi punca kepada permasalahan tersebut. ${ }^{19}$ Ini disokong oleh kajian bahawa wujud rungutan terhadap institusi zakat dalam pelaksanaan kutipan dan agihan zakat yang mengakibatkan keyakinan masyarakat kepada MAIN dan institusi zakat terjejas seterusnya enggan membayar zakat. ${ }^{20}$ Kajian seterusnya mendapati persepsi masyarakat turut mempengaruhi peningkatan dan pengurangan kutipan zakat secara langsung. ${ }^{21}$ Kajian lain mendapati keengganan responden membayar zakat disumbang oleh rasa tidak puas hati dengan pengagihan zakat oleh institusi zakat. Selain itu, ketidakyakinan kepada institusi zakat menyumbang kepada pembayaran langsung zakat tanpa melalui saluran formal. ${ }^{22}$ Pembayaran zakat secara terus kepada asnaf tanpa melalui institusi zakat yang berautoriti penuh terhadap kutipan dan agihan zakat menyebabkan ketirisan kutipan yang signifikan saban tahun. ${ }^{23}$ Pengurusan pungutan dan agihan zakat yang cekap

17 Hairunnizam Wahid, Sanep Ahmad, Mohd Ali Mohd Nor \& Maryam Abd Rashid, 'Prestasi Kecekapan Pengurusan Kewangan dan Pengurusan Agihan Zakat: Perbandingan antara Majlis Agama Islam Negeri', 21-35.

18 Teh Suhaila Tajuddin, Aza Shahnaz Azman \& Noraini Shamsuddin, 'Impak Agihan Zakat Terhadap Kualiti Asnaf di Selangor,' Proceeding $2^{\text {nd }}$ International Conference on Economics \& Banking (Bangi: Faculty of Management \& Muamalah, KUIS, 2016), 226-237.

19 Md Hairi Md Hussain, Kamil Md. Idris \& Ram Al Jaffri Saad, 'Ketelusan di dalam Tadbir Urus Institusi Zakat', Prosiding Seminar Isu-Isu Kontemporari Zakat di Malaysia (Langkawi: Pusat Islam UUM, 2012), 63-74.

20 Ahmad Hidayat Buang \& Saidatul Badrul Mohd Said, 'Pentadbiran Zakat dan Kesedaran Masyarakat Islam Membayar Zakat di Daerah Kota Belud Sabah', 125134.

21 Ismail Ahmad \& Masturah Main, 'The Efficiency of Zakat Collection and Distribution: Evidence from Two Stage Analysis,' Journal of Economics and Development, 35/3 (2014): 133-170.

22 Hairunnizam Wahid, Sanep Ahmad \& Radiah Abdul Kader, 'Pengagihan Zakat oleh Institusi Zakat di Malaysia: Mengapa Masyarakat Islam Tidak Berpuas Hati?’ Jurnal Syariah, 17/1 (2009): 89-112.

23 Fidlizan Muhammad, Mohd Yahya Mohd Hussin, Azila Abdul Razak \& Salwa Amirah Awang, 'Ketirisan Bayaran Zakat Terhadap Institusi Formal di Malaysia,' Sains Humanika, 5/1 (2015): 27-32. 
turut dikekang oleh kesedaran membayar zakat yang rendah. ${ }^{24}$ Ini disokong oleh kajian yang membincangkan isu dan cabaran pungutan zakat di Sabah terutamanya kesedaran masyarakat terhadap kewajipan menunaikan zakat dan operasi institusi zakat memandangkan jumlah pungutan zakat masih kurang berbanding perolehan cukai. ${ }^{25}$ Justeru, bagi memastikan keberkesanan dan kecekapan institusi zakat dalam menguruskan dana zakat, tadbir urus yang baik amat dituntut. Kepuasan hati semua pihak terhadap institusi zakat dan penyampaian perkhidmatan yang berkualiti dapat dicapai dengan tadbir urus yang baik. ${ }^{26}$

Walaupun kebanyakan kajian lepas membincangkan mengenai prestasi kecekapan institusi zakat, namun kajian mengenai kecekapan agihan zakat masih kurang. ${ }^{27}$ Kebanyakan kajian hanya tertumpu mengenai kecekapan tadbir urus institusi zakat dan masalah keyakinan masyarakat terhadap institusi zakat ${ }^{28}$ dan juga membincangkan kerangka akauntabiliti pengurusan dana zakat tanpa menguji prestasi institusi zakat. ${ }^{29}$ Selain itu, kebanyakan kajian lepas hanya membincangkan mengenai kepatuhan membayar zakat dan analisis kutipan yang tertumpu pada ketirisan zakat serta mengenai pentadbiran zakat dan kesedaran dalam membayar zakat seperti kajian mengenai statistik pungutan dan agihan serta faktor kesedaran dalam membayar zakat di salah satu daerah di Sabah $^{30}$ serta kajian lain seumpamanya yang membincangkan

24 Ahmad Hidayat Buang \& Saidatul Badrul Mohd Said, 'Pentadbiran Zakat dan Kesedaran Masyarakat Islam Membayar Zakat di Daerah Kota Belud Sabah', 125134.

25 Dayangku Aslinah Abd. Rahim, 'Zakat Potential in Sabah: Issues and Challenges,' 991-997.

26 Md Hairi Md Hussain, Kamil Md. Idris \& Ram Al Jaffri Saad, 'Ketelusan di dalam Tadbir Urus Institusi Zakat', 63-74.

27 Eza Ellany Abdul Lateff, Mohd Rizal Palil \& Mohamat Sabri Hassan, 'Prestasi Kecekapan Agihan Kewangan dan Bukan Kewangan dalam Kalangan Institusi Zakat di Malaysia,' 51-60.

28 Mohd Yahya Mohd Hussin, Fidlizan Muhammad \& Mohamad Ali Roshidi Ahmad, 'Kepatuhan Membayar Zakat: Analisis Kutipan dan Ketirisan Zakat Fitrah di Selangor,' Jurnal Syariah, 21/2 (2013): 191-206.

29 Ram Al Jaffri Saad, Norazita Marina Abdul Aziz \& Norfaiezah Sawandi, 'Islamic Accountability Framework in the Zakat Funds Management' Procedia-Social and Behavioral Sciences, 164 (2014): 508-515.

30 Ahmad Hidayat Buang \& Saidatul Badrul Mohd Said, 'Pentadbiran Zakat dan Kesedaran Masyarakat Islam Membayar Zakat di Daerah Kota Belud Sabah', 125134. 
faktor kesedaran membayar zakat dan cabaran pungutan zakat di Sabah. ${ }^{31}$ Oleh itu, kajian ini akan mengkaji aspek pengukuran prestasi nisbah aliran tunai sebagai proksi kepada prestasi kewangan Majlis Agama Islam dan prestasi kecekapan agihan pusat zakat dengan lebih terperinci.

\section{METODOLOGI KAJIAN}

Kajian ini dijalankan menggunakan data sekunder yang diperolehi melalui laporan kewangan tahunan Majlis Ugama Islam Sabah (MUIS) dan Laporan Zakat Pusat Zakat Sabah (PZS-MUIS) daripada tahun 2000 sehingga 2013 dan data berkaitan daripada Jabatan Wakaf, Zakat dan Haji (JAWHAR). Data yang diperoleh merupakan laporan tahunan dan penyata kewangan terkini yang telah diaudit dan disahkan oleh Ketua Audit Negara dan tiada data terbaru. Data kemudian dianalisis menggunakan beberapa kaedah analisis. Bagi analisis prestasi kewangan MUIS, kaedah analisis nisbah aliran tunai telah diguna pakai berpandukan kajian terdahulu ${ }^{32}$ seperti yang ditunjukkan dalam Jadual 1.

Jadual 1: Penerangan Nisbah Aliran Tunai yang Digunakan

\begin{tabular}{lccc}
\hline \multicolumn{1}{c}{ Nisbah } & Formula & Penanda Aras & Ukuran \\
\hline $\begin{array}{l}\text { ATO kepada LS } \\
\text { ATO kepada JL }\end{array}$ & ATO/LS & $>0.4$ & Kecairan \\
Margin Aliran Tunai & ATO/JL & $>0.2$ & Kesolvenan \\
& & nilai positif & Keuntungan \\
$\begin{array}{l}\text { Nota: ATO = Aliran Tunai Aktiviti Operasi, LS = Liabiliti Semasa, JL = Jumlah Liabiliti } \\
\text { JP = Jumlah Pendapatan } \\
\text { Sumber: Faiz, Hairunnizam \& Sanep (2014) }\end{array}$
\end{tabular}

Bagi prestasi pengurusan agihan zakat pula, ia terbahagi kepada dua iaitu prestasi kewangan dan bukan kewangan. Prestasi kewangan melibatkan skor kecekapan lebihan zakat (SKORLZ) manakala prestasi bukan kewangan melibatkan skor kecekapan keutamaan asnaf (SKORKA). Skor kecekapan lebihan zakat (SKORLZ) dibentuk berdasarkan peratusan jumlah lebihan

31 Dayangku Aslinah Abd. Rahim, 'Zakat Potential in Sabah: Issues and Challenges,' 991-997.

32 Faiz Mat Isa, Hairunnizam Wahid \& Sanep Ahmad, 'Pengukuran Prestasi Menggunakan Nisbah Aliran Tunai dan Nisbah Tradisi: Perbandingan di Antara Majlis Agama Islam Selangor dan Majlis Agama Islam dan Adat Melayu Perak' 310-325. 
wang zakat yang tidak diagihkan berbanding jumlah kutipan zakat. ${ }^{33}$ Skor ini menilai berapa banyak lebihan wang zakat dan peratusannya yang tidak diagihkan pada setiap akhir tahun. Kaedah pengiraan SKORLZ boleh dirujuk pada Persamaan 1.

SKORLZ $=\underline{\text { Jumlah Lebihan (Jumlah Kutipan - Jumlah Agihan) }}$ Persamaan (1) Jumlah Kutipan

Skor kecekapan lebihan zakat diukur dalam lingkungan nilai antara 0 hingga 1. Nilai 0 menandakan bahawa skor adalah pada tahap terbaik dan sangat cekap. Ini bermakna semakin rendah jumlah lebihan zakat berbanding jumlah kutipan semakin cekap prestasi agihan zakat. Namun, terdapat kemungkinan institusi zakat melaksanakan agihan zakat melebihi kutipan zakat yang diperoleh pada tahun semasa. Situasi ini mungkin disebabkan wujudnya lebihan agihan zakat pada tahun sebelumnya yang diagihkan pada tahun semasa. Keadaan ini mengakibatkan nilai lebihan zakat akan menjadi negatif dan menunjukkan berlaku ketidakcekapan dalam pengurusan agihan zakat. Agihan yang cekap sepatutnya dilakukan pada tahun semasa kutipan wang zakat diperoleh. ${ }^{34}$

Skor kecekapan keutamaan asnaf (SKORKA) dibentuk berpandukan kepada keutamaan asnaf yang wajib didahulukan mengikut turutan di dalam alQuran dan al-Sunnah, berlandaskan mazhab Imam Shāfi' 1 . Menurut pandangan Imam Shāfi ‘'i, terdapat empat golongan asnaf yang perlu diberi keutamaan terlebih dahulu sebelum lainnya dalam menerima agihan zakat iaitu al-fuqara ${ }^{\text {, }}$ (golongan fakir), al-masākīn (golongan miskin), al-ghārimīn (golongan berhutang) dan ibn sabīl (golongan yang bermusafir/dalam perjalanan). ${ }^{35}$ Manakala berdasarkan hujah bahawa sekurang-kurangnya agihan memadai dilaksanakan kepada tiga golongan asnaf, maka amil (pengutip zakat) berada pada kedudukan ketiga selepas asnaf fakir dan miskin. Berdasarkan turutan keutamaan ini, institusi zakat perlu memastikan kelima-lima asnaf di atas mendapat agihan zakat sepatutnya sebelum agihan dilakukan kepada asnaf lain yang disebut di dalam al-Quran iaitu mualaf (golongan baru memeluk Islam), al-riqāb (hamba) dan fì sabīlillah (golongan berjuang di jalan Allah).

33 Eza Ellany Abdul Lateff, Mohd Rizal Palil \& Mohamat Sabri Hassan, 'Prestasi Kecekapan Agihan Kewangan dan Bukan Kewangan dalam Kalangan Institusi Zakat di Malaysia,' 51-60.

34 Eza Ellany Abdul Lateff, Mohd Rizal Palil \& Mohamat Sabri Hassan, 'Prestasi Kecekapan Agihan Kewangan dan Bukan Kewangan dalam Kalangan Institusi Zakat di Malaysia,' 51-60.

35 'Abd al-Raḥmān al-Jazirī, Kitāb al-Fiqh 'ala al-Madhāhib al-Arba'ah (Beirūt: Dār al-Kutub al-'Ilmiyyah, 2003), 562-566. 
Skor keutamaan asnaf (SKORKA) diukur dengan menjumlahkan perbezaan skor antara skor agihan sebenar Mazhab Imam Shāfi '̄i dengan skor agihan institusi zakat bagi lapan kategori asnaf, kemudian dibahagikan dengan jumlah perbezaan skor maksimum yang diperoleh bagi kelapan-lapan kategori asnaf. Jumlah perbezaan skor maksimum adalah 26 (rujuk Jadual 2). ${ }^{36}$ Nilai skor keutamaan asnaf (SKORKA) pula akan berada dalam lingkungan nilai 0 hingga 1, yang mana nilai 0 adalah skor yang paling cekap. ${ }^{37}$ Kaedah pengiraan SKORKA boleh dirujuk seperti pada Persamaan 2.

SKORKA $=\quad$ Jumlah perbezaan skor bagi 8 kategori asnaf $\quad$ Persamaan (2) (skor agihan sebenar - skor agihan institusi) jumlah perbezaan skor maksimum (26)

Jadual 2: Pengiraan Perbezaan Skor Maksimum untuk SKORKA

\begin{tabular}{ccc}
\hline $\begin{array}{c}\text { Skor Agihan } \\
\text { Sebenar }\end{array}$ & $\begin{array}{c}\text { Skor Agihan Institusi } \\
\text { Terendah }\end{array}$ & $\begin{array}{c}\text { Perbezaan Skor } \\
\text { Maksimum }\end{array}$ \\
\hline 1 & 6 & 5 \\
2 & 6 & 4 \\
3 & 6 & 3 \\
4 & 5 & 1 \\
5 & 4 & 1 \\
6 & 3 & 3 \\
6 & 2 & 4 \\
6 & 1 & 5 \\
\hline
\end{tabular}

Sumber: Eza Ellany Abdul Lateff et al. (2014).

Skor agihan sebenar adalah skor yang diberikan kepada lapan kategori asnaf mengikut keutamaan mazhab Imam Shāfi ‘ī dan diukur dalam lingkungan skala skor 1 hingga 6 seperti di Jadual 3. Kajian hanya menggunakan 6 skala skor disebabkan tiga lagi golongan asnaf iaitu mualaf, al-riqāb dan $f i$ sabīlillah tidak dinyatakan turutan keutamaannya oleh mazhab Imam Shāfi ‘̄i.

36 Eza Ellany Abdul Lateff, Mohd Rizal Palil \& Mohamat Sabri Hassan, 'Prestasi Kecekapan Agihan Kewangan dan Bukan Kewangan dalam Kalangan Institusi Zakat di Malaysia,' 51-60.

37 Eza Ellany Abdul Lateff, Mohd Rizal Palil \& Mohamat Sabri Hassan, 'Prestasi Kecekapan Agihan Kewangan dan Bukan Kewangan dalam Kalangan Institusi Zakat di Malaysia,' 51-60. 
Ini bermakna asnaf yang sepatutnya menerima agihan zakat yang banyak berdasarkan keutamaan mereka mengikut mazhab Imam Shāfi' $1 \overline{\text { adalah asnaf }}$ fakir, diikuti miskin, amil, al-ghārimīn, ibn sabìl, dan seterusnya dibahagikan secara sama rata antara mualaf, al-riqāb dan fì sabìlillah.

Jadual 3: Skor Agihan Sebenar Mazhab Imam Shāfi ‘⿳亠

\begin{tabular}{llc}
\hline Bil & \multicolumn{1}{c}{ Kategori Asnaf } & Skor Agihan \\
\hline 1. & al-Fuqarā' (golongan fakir) & 1 \\
2. & al-Masākīn (golongan miskin) & 2 \\
3. & Amil & 3 \\
4. & al-Ghārimīn (golongan berhutang) & 4 \\
5. & Ibn Sabūl (golongan bermusafir) & 5 \\
6. & Mualaf & 6 \\
7. & al-Riqāb (hamba) & 6 \\
8. & Fì Sabīlillah (golongan berjuang di jalan Allah) & 6 \\
\hline
\end{tabular}

Sumber: Eza Ellany Abdul Lateff et al. (2014).

Skor agihan institusi pula adalah skor yang diberikan berdasarkan turutan jumlah agihan zakat untuk setiap kategori asnaf oleh institusi zakat iaitu nilai kewangan agihan zakat dijadikan asas dalam menentukan skor agihan setiap asnaf. Skor ini ditentukan dengan menilai asnaf manakah yang menerima agihan zakat banyak sehingga agihan zakat yang sedikit oleh institusi zakat bagi suatu tempoh tahun kewangan tertentu. Setiap kategori asnaf yang menerima jumlah agihan terbanyak akan diberikan turutan skor 1 hingga 5 manakala tiga kategori asnaf yang menerima agihan yang sedikit pula masing-masing akan diberikan skor 6. Penentuan skor maksimum agihan institusi terendah berlaku apabila asnaf fì sabīlillah, al-riqāb dan mualaf menerima agihan terbanyak oleh institusi zakat manakala asnaf fakir, miskin dan amil yang sepatutnya mendapat agihan terbanyak berdasarkan keutamaan pula menerima agihan yang sedikit bagi suatu tempoh tahun kewangan dan ini dapat dilihat seperti di Jadual 4. 
Jurnal Syariah, Jil. 25, Bil. 3 (2017) 415-452

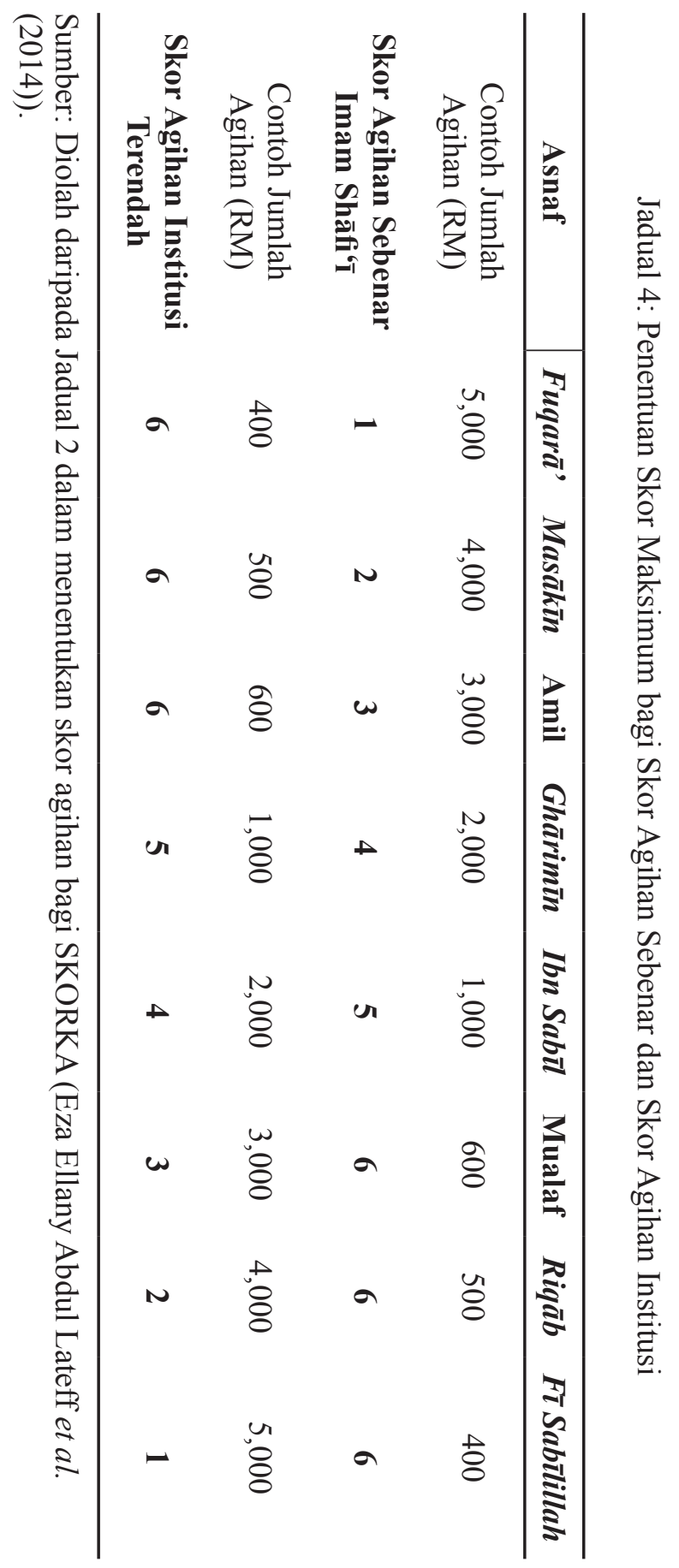


Bagi melihat prestasi agihan zakat dengan lebih terperinci, analisis corak agihan zakat kepada setiap kategori asnaf dilakukan dan data dianalisis menggunakan regresi mudah kuasa dua terkecil mengikut kategori asnaf $\mathrm{f}^{38}$ bagi melihat corak agihan zakat dan sebarang perubahan yang berlaku sebelum dan selepas penubuhan Pusat Zakat Sabah pada 2007. Analisis data dilakukan bagi tempoh 13 tahun bermula dari tahun 2001 hingga 2013 (tidak termasuk tahun 2000 bagi tujuan memastikan keseragaman data yang dianalisis). Menurut Roscoe (1975) dalam penentuan saiz sampel bagi suatu kajian, sampel data di antara 10 hingga 20 adalah memadai bagi kajian yang bersifat sederhana yang tidak memerlukan regresi pemboleh ubah pelbagai serta kawalan dan manipulasi ketat pemboleh ubah. Isaac dan Michael (1995) pula menyatakan kajian menggunakan saiz data yang kecil memadai bagi suatu kajian yang bersifat pengujian awalan atau eksperimen. ${ }^{39}$ Ini bertepatan dengan sifat kajian ini yang merupakan suatu kajian yang julung kali dilakukan terhadap kecekapan pengurusan kewangan dan agihan zakat bagi majlis agama dan institusi zakat di Sabah serta limitasi data yang diperoleh iaitu laporan kewangan tahunan dan penyata kewangan yang telah diaudit dan disahkan oleh Ketua Audit Negara dan ketiadaan data terbaru. Data-data yang dianalisis kemudiannya dipersembahkan ke dalam bentuk jadual dan graf bagi menunjukkan corak dan penekanan dalam agihan zakat. Model yang digunakan bagi tujuan analisis data adalah seperti yang ditunjukkan dalam Model 1.

$$
\mathrm{Y}=\mathrm{a}+\mathrm{bt} \quad \text { Persamaan (3) }
$$

Berdasarkan Model 1, Y adalah peratus agihan zakat mengikut asnaf yang terdiri daripada fakir, miskin, amil, mualaf, al-riqāb, al-ghārimīn, fì sabïlillah dan ibn sabīl, manakala t adalah nilai masa bagi corak. Lihat persamaan (3).

\section{HASIL KAJIAN}

Prestasi kecekapan pengurusan kewangan MUIS secara keseluruhannya adalah baik dan telah diukur seperti mana ditunjukkan dalam Jadual 5. Prestasi diukur dengan melakukan analisis ke atas prestasi kecairan, kesolvenan dan keuntungan. Bagi prestasi kecairan, kajian mendapati tahap kecairan Majlis

38 Rashidah Unos, Hairunnizam Wahid, Sanep Ahmad, 'Zakat: Analisis Perubahan Corak Agihan di Negeri Sembilan', Isu Kontemporari Agihan Zakat di Malaysia, ed. Nor Aini Ali et al. (Kuala Lumpur: Majlis Agama Islam Wilayah Persekutuan (MAIWP), 2015): 179-195.

39 Robin Hill, 'What Sample Size is Enough in Internet Survey Research,' Interpersonal Computing \& Technology, 6/3-4 (1998). 
Ugama Islam Sabah (MUIS) adalah sangat baik dengan nisbah kecairan melebihi nisbah minimum 40 peratus atau 0.40 pada tahun 2000, 2002 hingga 2005 dan 2009 hingga 2012. Nilai kecairan tertinggi dan terbaik dicatatkan pada tahun 2012 dengan nisbah kecairan sebanyak 2459 peratus atau 24.59 dan tahun 2002 dengan nisbah kecairan sebanyak 1325 peratus atau 13.25. Bagi tahun 2006 pula menunjukkan nisbah kecairan adalah 25 peratus atau 0.25 iaitu di bawah nilai nisbah minimum 40 peratus. Manakala prestasi kecairan tahap negatif berlaku pada tahun 2001, 2007, 2008, dan 2013.

Bagi prestasi kesolvenan pula, kajian mendapati tahap kesolvenan MUIS adalah pada tahap tidak sihat. Ini kerana hampir keseluruhan tahun mencatatkan nilai nisbah di bawah 20 peratus atau 0.20 kecuali tahun 2000 dan 2012 yang menunjukkan nilai nisbah kesolvenan 460 peratus atau 4.60 dan 50 peratus atau 0.50 secara respektif. Nilai nisbah negatif pula dicatatkan pada tahun 2001, 2007, 2008 dan 2013. Hasil analisis bagi pengukuran prestasi keuntungan MUIS pula mendapati ia berada pada tahap yang sangat baik. Nisbah margin aliran tunai bagi mengukur prestasi keuntungan merupakan indikasi keupayaan penjanaan tunai yang lebih baik..$^{40}$ Kajian mendapati bagi tahun 2000, 2002 hingga 2006 dan 2009 hingga 2012, nilai nisbah margin aliran tunai adalah bernilai positif menunjukkan prestasi keuntungan adalah sangat memberangsangkan. Nilai nisbah tertinggi pula dicatatkan pada tahun 2012 sebanyak 65.78 peratus dan tahun 2002 sebanyak 65.18 peratus. Namun, nilai nisbah negatif dicatatkan pada tahun 2001, 2007, 2008 dan 2013 dengan nilai nisbah negatif terendah adalah pada tahun 2007 sebanyak 90.48 peratus.

Melalui penelitian berpandukan Jadual 5, terdapat kesan yang sangat signifikan terhadap prestasi pengurusan kewangan bagi MUIS setelah penubuhan Pusat Zakat Sabah (PZS-MUIS) pada tahun 2007. Bagi prestasi pengurusan kewangan MUIS sebelum penubuhan PZS pada tahun 2007, nilai purata yang diperoleh adalah 3.25 peratus bagi nisbah kecairan, 0.06 peratus bagi nisbah kesolvenan dan 15.10 peratus bagi nisbah keuntungan. Peningkatan yang ketara berlaku bermula tahun 2007 apabila nilai purata yang dicatatkan adalah 3.38 peratus bagi nisbah kecairan iaitu meningkat sebanyak 0.13 peratus. Nilai purata bagi nisbah kesolvenan pula ialah 0.07 peratus iaitu meningkat sebanyak 0.01 peratus walaupun belum memenuhi kriteria kesolvenan iaitu lebih besar daipada 0.2 peratus. Namun, nilai purata bagi nisbah keuntungan pula menurun kepada 1.79 peratus iaitu penurunan sebanyak 13.31 peratus.

$40 \quad$ Eza Ellany Abdul Lateff, Mohd Rizal Palil \& Mohamat Sabri Hassan, 'Prestasi Kecekapan Agihan Kewangan dan Bukan Kewangan dalam Kalangan Institusi Zakat di Malaysia,' 51-60. 
Prestasi kecekapan agihan zakat pula diukur berdasarkan skor kecekapan lebihan zakat (prestasi agihan kewangan) dan skor kecekapan keutamaan asnaf (prestasi agihan bukan kewangan). Jadual 5 menunjukkan hasil analisis prestasi agihan zakat. Analisis dilakukan bagi mencapai objektif kajian iaitu menilai prestasi institusi zakat berdasarkan kedua-dua jenis prestasi agihan iaitu prestasi agihan berbentuk kewangan dan bukan kewangan. Kecekapan agihan dicapai apabila hampir kesemua derma yang diterima dibelanjakan sepenuhnya untuk projek-projek kebajikan yang dirangka. ${ }^{41}$ Kajian mendapati nilai 100 peratus atau skor agihan bernilai 0.00 merupakan agihan zakat yang optimum. ${ }^{42}$ Namun, disebabkan ketiadaan sebarang penanda aras bagi menilai kecekapan agihan dari sudut lebihan zakat, maka skor di bawah lingkungan 0.228 sudah dianggap berprestasi baik. ${ }^{43}$ Bagi skor kecekapan keutamaan asnaf pula didapati skor di bawah nilai 0.46 adalah skor kecekapan keutamaan asnaf terbaik berdasarkan kekerapan tertinggi nilai skor yang diperoleh dan turut menjadikan nilai skor di bawah nilai 0.228 sebagai skor kecekapan lebihan zakat terbaik. Sekiranya terdapat skor yang bernilai negatif, maka nilai tersebut akan digantikan dengan nilai 0 kerana tiada lebihan zakat semasa yang tidak diagihkan. Manakala nilai skor di bawah nilai 0.46 sebagai skor kecekapan keutamaan asnaf terbaik. ${ }^{44}$

Secara keseluruhannya, MUIS dan PZS-MUIS telah menunjukkan prestasi agihan zakat yang semakin meningkat dan memberangsangkan baik dari segi prestasi agihan kewangan dan agihan bukan kewangan walaupun nilai yang diperoleh kurang konsisten. Bagi prestasi agihan zakat dari segi agihan kewangan, hasil analisis kajian ini selari dengan dapatan kajian terdahulu yang menjadikan nilai skor di bawah nilai 0.228 peratus sebagai skor kecekapan lebihan zakat yang dianggap berprestasi baik walaupun belum mencapai kepada tahap agihan optimum 100 peratus. Berdasarkan Jadual 5, skor kecekapan

41 Andres-Alonso, de. P, Martin Cruz, N. \& Romero-Merino, M.E, 'The Governance of Nonprofit Organizations: Empirical Evidence from Nongovernmental Development Organizations in Spain,' Nonprofit and Voluntary Sector Quarterly, 35/4 (2006): 588-604.

42 Hairunnizam Wahid, Sanep Ahmad \& Radiah Abdul Kader, 'Pengagihan Zakat oleh Institusi Zakat Kepada Lapan Asnaf: Kajian di Malaysia,' Jurnal Pengurusan JAWHAR, 4/1 (2010): 141-170.

43 Eza Ellany Abdul Lateff, Mohd Rizal Palil \& Mohamat Sabri Hassan, 'Prestasi Kecekapan Agihan Kewangan dan Bukan Kewangan dalam Kalangan Institusi Zakat di Malaysia,' 51-60.

44 Eza Ellany Abdul Lateff, Mohd Rizal Palil \& Mohamat Sabri Hassan, 'Prestasi Kecekapan Agihan Kewangan dan Bukan Kewangan dalam Kalangan Institusi Zakat di Malaysia,' 51-60. 
lebihan zakat terbaik dicapai pada tahun 2007 apabila nilai skor adalah 0.00 yang menunjukkan tiada dana zakat yang tidak diagihkan sehingga berlakunya lebihan. Skor kecekapan lebihan zakat juga diperoleh pada tahun 2001, 2005, 2007 hingga 2011 dan 2013 apabila kesemua nilai skor berada di bawah nilai 0.228 terutamanya pada tahun 2007 yang mencatatkan skor kecekapan pada nilai optimum sebanyak 0.00 peratus. Manakala nilai skor terendah dicapai pada tahun 2002 dengan nilai skor 0.776 dan kurang cekap.

Jadual 5: Prestasi Aliran Tunai dan Kecekapan Agihan Zakat oleh MUIS/ PZS-MUIS

\begin{tabular}{cccccc}
\hline Tahun & $\begin{array}{c}\text { Kecairan } \\
\text { (ATO/LS) }\end{array}$ & $\begin{array}{c}\text { Kesolvenan } \\
\text { (ATO/JL) }\end{array}$ & $\begin{array}{c}\text { Keuntungan } \\
\text { (ATO/JP) }[\%]\end{array}$ & $\begin{array}{c}\text { Nilai } \\
\text { SKORLZ }\end{array}$ & $\begin{array}{c}\text { Nilai } \\
\text { SKORKA }\end{array}$ \\
\hline 2000 & 4.60 & $\mathrm{n} / \mathrm{a}$ & 18.83 & 0.319 & 0.462 \\
2001 & -6.30 & $\mathrm{n} / \mathrm{a}$ & -47.14 & 0.146 & 0.462 \\
2002 & 13.25 & 0.12 & 65.18 & 0.776 & 0.385 \\
2003 & 6.34 & 0.02 & 18.49 & 0.458 & 0.308 \\
2004 & 3.49 & 0.02 & 19.63 & 0.325 & 0.385 \\
2005 & 1.14 & 0.02 & 26.06 & 0.206 & 0.385 \\
2006 & 0.25 & 0.01 & 4.63 & 0.266 & 0.385 \\
\hline Purata (1) & 3.25 & 0.06 & 15.10 & 0.357 & 0.396 \\
\hline 2007 & -3.89 & -0.12 & -90.48 & 0.000 & 0.385 \\
2008 & -0.51 & -0.02 & -12.27 & 0.186 & 0.308 \\
2009 & 1.29 & 0.05 & 12.91 & 0.041 & 0.462 \\
2010 & 2.82 & 0.08 & 25.96 & 0.209 & 0.385 \\
2011 & 1.73 & 0.06 & 17.57 & 0.044 & 0.231 \\
2012 & 24.59 & 0.50 & 65.78 & 0.246 & 0.385 \\
2013 & -2.34 & -0.04 & -6.97 & 0.015 & 0.385 \\
\hline Purata (2) & 3.38 & 0.07 & 1.79 & 0.12 & 0.363 \\
\hline
\end{tabular}

Nota $\quad$ ATO/LS; nilai $>0.4$ memenuhi kriteria kecairan, ATO/JL; nilai > 0.2 memenuhi kriteria kesolvenan, ATO/JP; nilai positif memenuhi kriteria keuntungan.

SKORLZ: nilai antara 0 hingga 1; lebihan zakat di bawah nilai 0.228 adalah sebagai skor terbaik.

SKORKA: nilai skor di bawah 0.46 sebagai skor kecekapan keutamaan asnaf terbaik. Purata (1): bagi tahun 2000 sehingga 2006; sebelum penubuhan PZS.

Purata (2): bagi tahun 2007 sehingga 2013; selepas penubuhan PZS.

Sumber: Diolah daripada analisis Laporan Kewangan Tahunan Majlis Ugama Islam Sabah tahun 2000-2013, Laporan Zakat Pusat Zakat Sabah (MUIS) tahun 2000-2013. 
Berdasarkan Jadual 5 juga, prestasi agihan zakat bagi agihan bukan kewangan diukur. Hasil analisis kajian juga selari dengan dapatan kajian terdahulu yang mengambil nilai skor di bawah nilai 0.46 sebagai skor kecekapan keutamaan asnaf terbaik. Kajian ini mendapati kesemua nilai skor pada tahun 2002 hingga 2008 dan seterusnya pada tahun 2010 hingga 2013 adalah di bawah nilai 0.46 peratus yang menunjukkan tahap kecekapan yang baik. Nilai skor terbaik dan paling cekap diperoleh pada tahun 2011 dengan nilai skor 0.231 peratus. Ini menunjukkan keseluruhan dana zakat telah diagihkan dengan hampir mengikuti turutan keutamaan kategori asnaf mazhab Imam Shāfi‘ ${ }^{\text {. Sebaliknya }}$ bagi tahun 2000, 2001 dan 2009 pula nilai skor adalah di atas nilai 0.46 dan kurang cekap.

Bagi prestasi pengurusan agihan zakat sebelum penubuhan PZS, nilai purata bagi SKORLZ dan SKORKA mencatatkan nilai skor sebanyak 0.357 peratus dan 0.396 peratus. Nilai skor lebihan zakat adalah kurang cekap kerana masih berada di atas nilai 0.228 peratus manakala nilai skor keutamaan asnaf pula adalah cekap kerana berada di bawah nilai 0.46 peratus. Namun, setelah penubuhan PZS, nilai purata bagi nilai skor lebihan zakat mencatatkan nilai terbaik 0.12 dan cekap iaitu peningkatan sebanyak 0.237 peratus. Begitu juga dengan nilai purata bagi skor keutamaan asnaf yang kekal meningkat kepada 0.363 iaitu peningkatan sebanyak 0.033 peratus berbanding sebelum penubuhan PZS. Kedua-dua nilai SKORLZ dan SKORKA setelah penubuhan PZS menunjukkan peningkatan yang stabil, malah pada tahun 2007 juga nilai skor lebihan zakat meningkat secara mendadak dengan mencatatkan nilai optimum 0.00 peratus atau 100 peratus yang menunjukkan kecekapan lebihan zakat terbaik dan seterusnya meningkat pada tahun-tahun berikutnya. 
Jurnal Syariah, Jil. 25, Bil. 3 (2017) 415-452

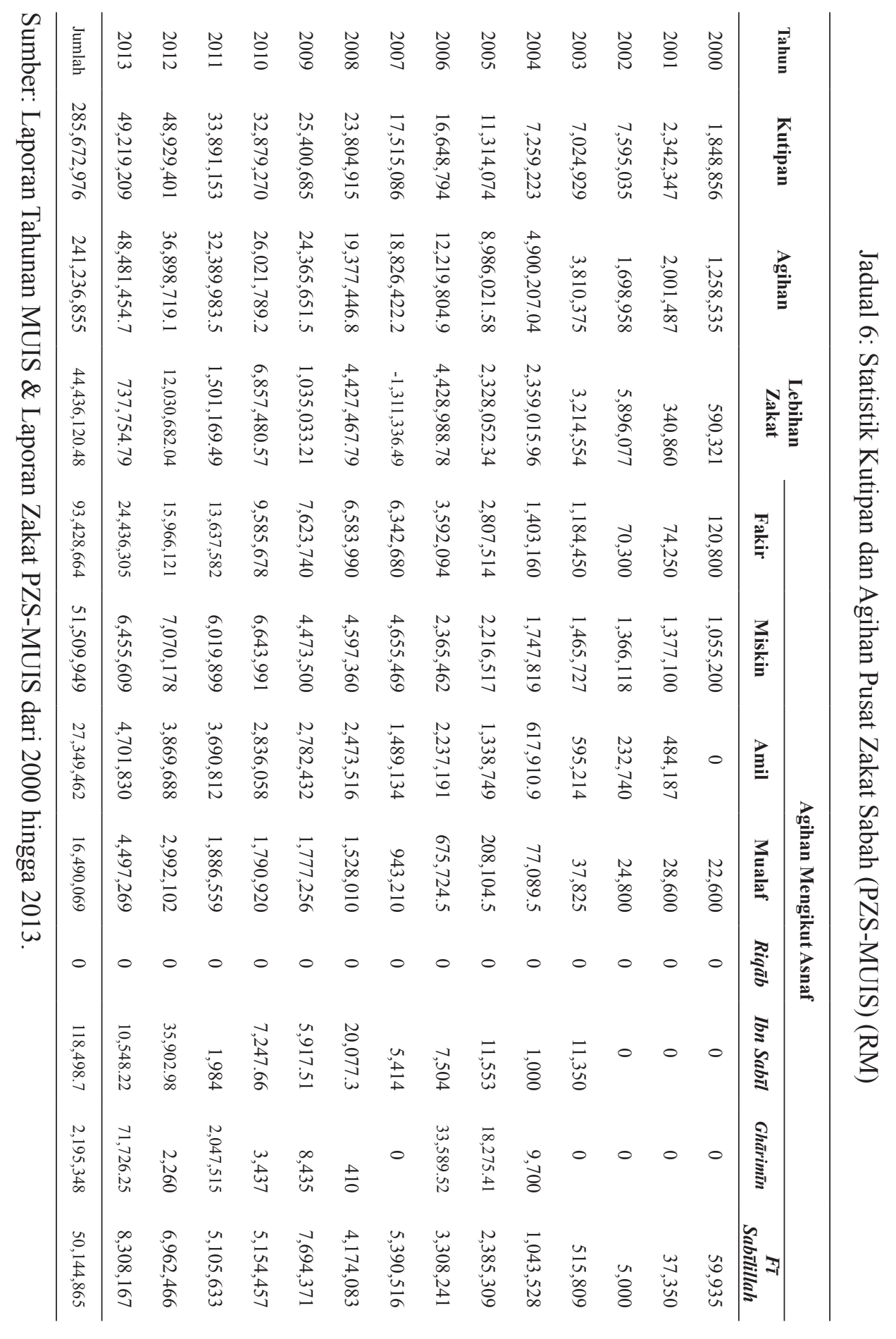


Berpandukan Jadual 6, hasil kajian mendapati prestasi kutipan dan agihan zakat adalah sangat memberangsangkan dengan jumlah hasil kutipan dan agihan zakat sepanjang tempoh dari tahun 2000 sehingga 2013 sentiasa meningkat dari tahun ke tahun. Keadaan ini merupakan sesuatu yang menggalakkan kerana kutipan yang meningkat membolehkan agihan dana zakat disalurkan dengan lebih menyeluruh meliputi keseluruhan kategori asnaf yang berhak menerima zakat selaras dengan tuntutan dan perintah Islam.

Secara keseluruhannya, didapati corak agihan zakat oleh PZS sebelum dan selepas ia diberikan nafas baharu tidak mengalami sebarang perubahan yang ketara. Agihan dana zakat sebelum dan selepas penubuhan PZS pada 2007 masih dibahagikan kepada lapan kategori asnaf iaitu asnaf fakir, miskin, amil, mualaf, al-riqāb, ibn sabīl, al-ghārimīn dan fì sabïlillah, walaupun asnaf alriqāb tidak menerima sebarang agihan kerana PZS masih mengikut perintah agihan yang telah ditetapkan di dalam al-Quran dan mengguna pakai takrifan al-riqāb daripada kitab-kitab terdahulu serta tidak diharmonikan dengan keadaan semasa. Jika diteliti dengan lebih mendalam, terdapat tiga golongan asnaf yang menerima agihan yang terbanyak iaitu asnaf fakir, miskin, dan $f \imath$ sabilillah. Ini terbukti apabila agihan zakat bagi ketiga-tiga kategori asnaf ini semakin meningkat saban tahun dengan jumlah keseluruhan agihan bagi asnaf fakir adalah sebanyak RM 93,428664, asnaf miskin sebanyak RM 51,509,949 dan asnaf $f i$ sabillillah sebanyak RM 50,144,865. Bagi asnaf fakir, jumlah agihan yang dicatatkan pada tahun 2000 adalah sebanyak RM 120,800 dan meningkat kepada RM 24,436,305 pada tahun 2013. Keadaan yang sama turut berlaku kepada asnaf miskin dengan jumlah agihan pada tahun 2000 sebanyak RM 1,055,200 dan meningkat kepada RM 6,455,609 pada tahun 2013. Bagi asnaf $f i$ sabilillah pula, jumlah agihan pada tahun 2000 adalah sebanyak RM 59,935 yang akhirnya meningkat kepada RM 8,308,167 pada tahun 2013.

Melalui Jadual 6 juga dapat diperhatikan agihan zakat kepada asnaf mualaf turut meningkat saban tahun, walaupun jumlahnya tidak sebesar asnaf fakir, miskin danfi sabilillah. Ini terbukti dengan jumlah agihan zakat hanya sebanyak RM 22,600 pada tahun 2000 yang meningkat sehingga RM 4,497,269 pada tahun 2013. Bagi asnaf amil, sudah semestinya akan memperoleh bahagian sendiri sebagai imbuhan mereka kerana ia melibatkan aktiviti pengurusan zakat dengan agihan yang diterima oleh asnaf amil secara keseluruhannya sebanyak RM 27,349,462. Agihan bagi asnaf ibn sabïl dan al-ghärimīn pula adalah tidak konsisten dengan berlaku peningkatan dan pengurangan dalam jumlah agihan yang diterima dengan masing-masing jumlah agihan keseluruhan sebanyak RM 118,498 dan RM 2,195,348. Namun, tiada perubahan yang ketara dilihat dalam agihan bagi kedua-dua kategori asnaf ini kerana agihannya lebih berdasarkan kepada mengikut keperluan semasa dan permintaan masyarakat. 
Walau bagaimanapun, kesemua kategori asnaf masih diberikan perhatian dan mendapat agihan yang sewajarnya daripada PZS sendiri dan ia merupakan suatu perkembangan yang baik.

Hubungan antara prestasi kecekapan pengurusan kewangan daripada aspek kecairan, kesolvenan dan keuntungan dengan prestasi kecekapan agihan zakat daripada aspek lebihan zakat dan keutamaan asnaf telah dirumuskan melalui Jadual 5. Secara keseluruhannya, kajian mendapati terdapat hubungan yang signifikan antara prestasi kecekapan pengurusan kewangan dengan prestasi kecekapan agihan zakat dan prestasi yang baik dapat ditunjukkan melalui nilai yang telah digelapkan. Kajian ini berjaya membuktikan secara deskriptif wujud hubungan antara prestasi pengurusan kewangan MUIS dan prestasi kecekapan agihan zakat oleh MUIS dan PZS-MUIS sebagai institusi yang bertanggungjawab dalam urusan mengutip dan mengagihkan dana zakat.

\section{ANALISIS CORAK AGIHAN ZAKAT}

Daripada hasil analisis terperinci melibatkan prestasi agihan zakat, Jadual 7 menunjukkan peratusan agihan dana zakat bagi setiap kategori asnaf sepanjang tempoh 13 tahun bermula dari tahun 2001 hingga 2013 (tidak termasuk tahun 2000 bagi tujuan keseragaman data yang dianalisis). Jadual 8 pula menunjukkan hasil regresi yang telah dijalankan. 
Kecekapan Pengurusan Kewangan dan Agihan Zakat: Kajian di Majlis Ugama Islam Sabah (MUIS)

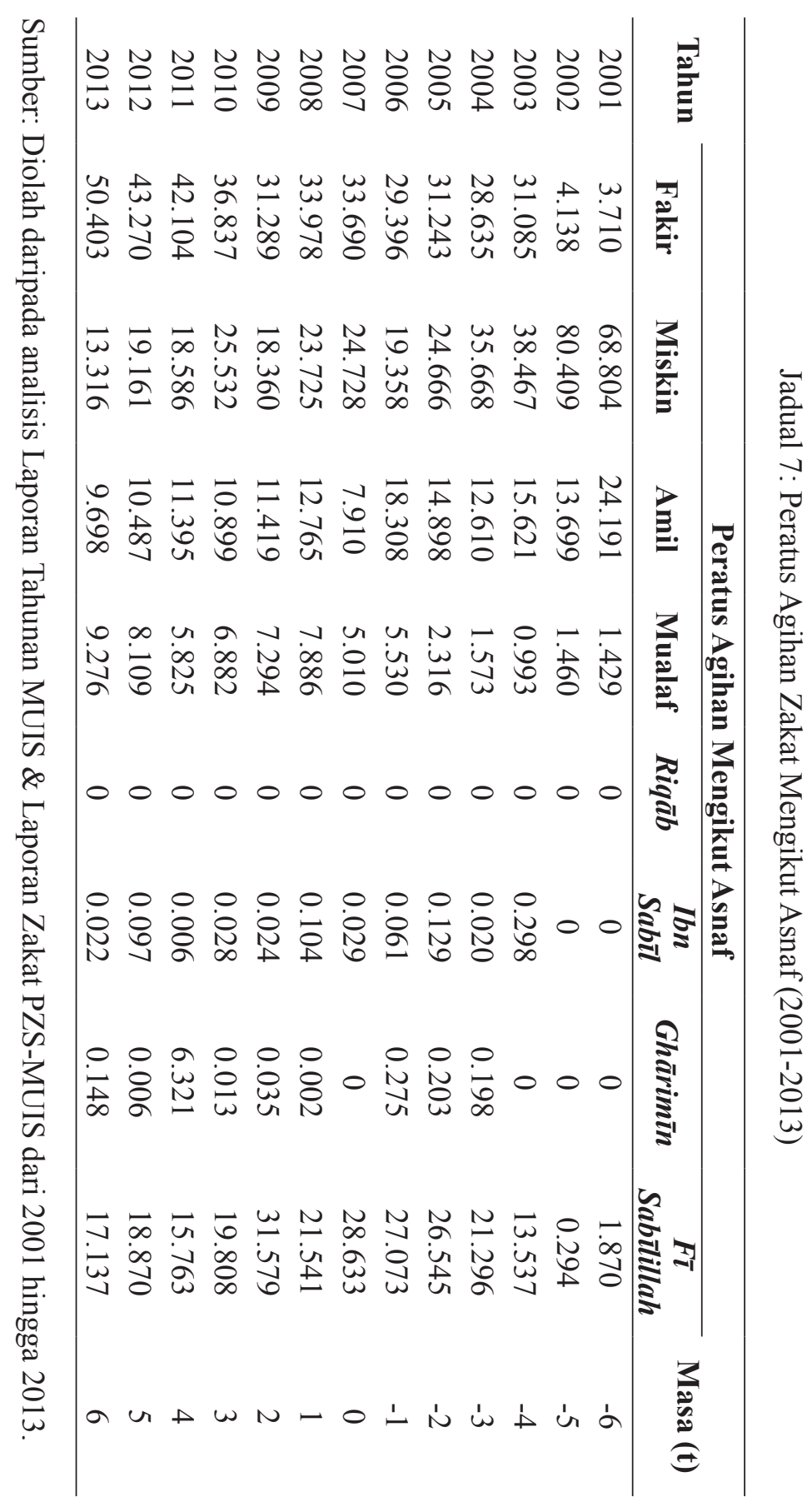


Jadual 8: Hasil Regresi Peratus Agihan Zakat Mengikut Asnaf (2001-2013)

\begin{tabular}{|c|c|c|c|c|c|c|c|c|}
\hline \multirow{2}{*}{$\begin{array}{c}\text { Pemboleh } \\
\text { ubah }\end{array}$} & \multicolumn{8}{|c|}{ Asnaf (Y) } \\
\hline & Fakir & Miskin & Amil & Mualaf & $R i q \bar{a} b$ & Ibn sabīl & Ghārimīn & $\begin{array}{c}F \bar{\imath} \\
\text { Sabülillah }\end{array}$ \\
\hline c (a) & 30.7521 & 31.5984 & 13.3679 & 4.8909 & 0.0000 & 0.0629 & 0.5539 & 18.7646 \\
\hline$t(b)$ & 3.0175 & -4.1612 & -0.7558 & 0.7027 & 0.0000 & -0.0038 & 0.1376 & 1.0631 \\
\hline t-statistik & 5.9365 & -4.3213 & -3.2041 & 7.7868 & $\mathrm{n} / \mathrm{a}$ & -0.6099 & 1.0764 & 1.6159 \\
\hline Prob. & 0.0001 & 0.0012 & 0.0084 & 0.0000 & 1.000 & 0.5543 & 0.3048 & 0.1344 \\
\hline
\end{tabular}

Sumber: Diolah daripada analisis Laporan Tahunan MUIS \& Laporan Zakat PZS-MUIS dari 2001 hingga 2013.

Melalui Rajah 1, kajian mendapati corak agihan zakat bagi asnaf fakir adalah semakin meningkat dengan peningkatan yang ketara berlaku setelah penubuhan PZS pada tahun 2007. Keadaan ini disebabkan tindakan daripada PZS dalam mempelbagaikan program bantuan ke atas golongan fakir seperti bantuan am, kewangan dan sara hidup, bantuan bulanan, modal perniagaan meliputi pertanian, penternakan, perkhidmatan dan bantuan kelengkapan perniagaan. Ini juga selaras dengan dasar yang diutamakan oleh Kerajaan Negeri Sabah melalui pelan pembangunan Kerajaan Negeri Sabah atau "Halatuju" dalam membasmi kemiskinan tegar atau lebih sesuai ditakrifkan sebagai fakir dengan pewujudan bantuan berbentuk keusahawanan yang dapat membantu golongan ini keluar daripada kepompong kemiskinan dan menjana pendapatan sendiri serta mampu berusaha ke arah kehidupan yang lebih baik. Berdasarkan Jadual 8, hasil regresi menunjukkan bahawa dengan peningkatan 1 unit dalam tahun, maka peratus agihan zakat untuk asnaf fakir akan meningkat sebanyak 3.02 peratus. Corak agihan dana zakat bagi asnaf fakir didapati meningkat dan signifikan pada aras keertian 5 peratus. 
Rajah 1: Trend Peratusan Agihan Zakat Kepada Asnaf oleh PZS-MUIS (2001-2013)
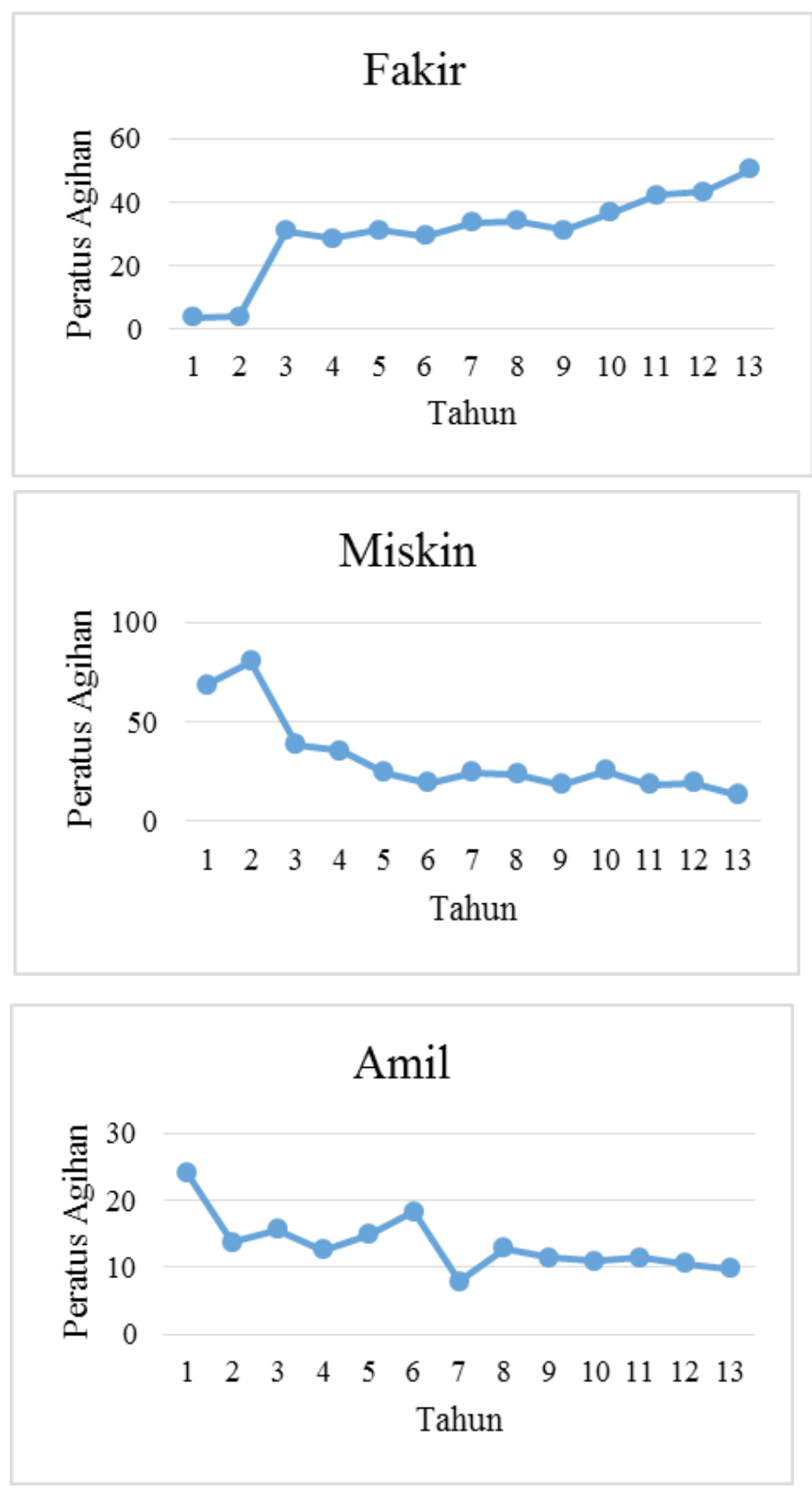

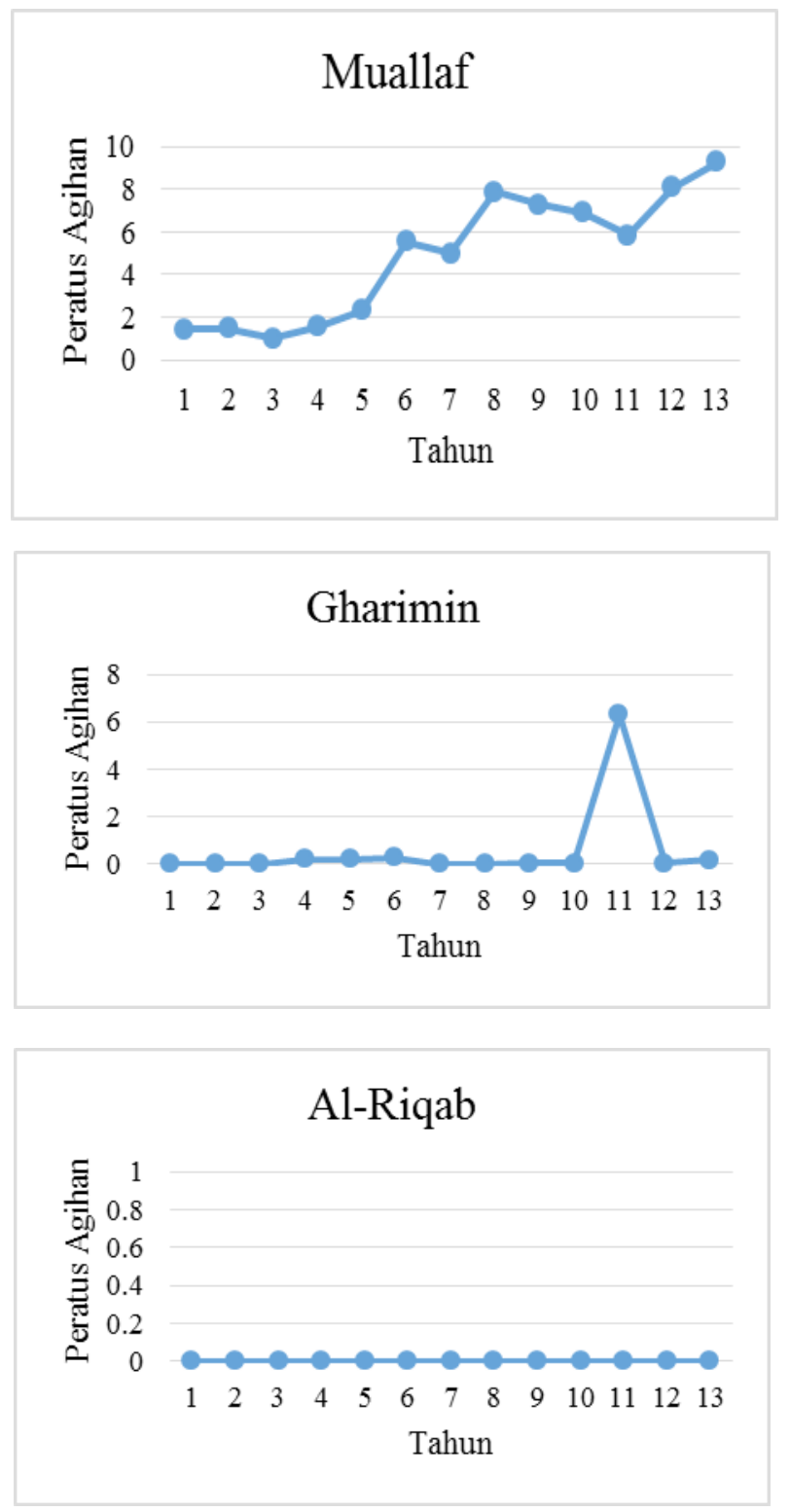

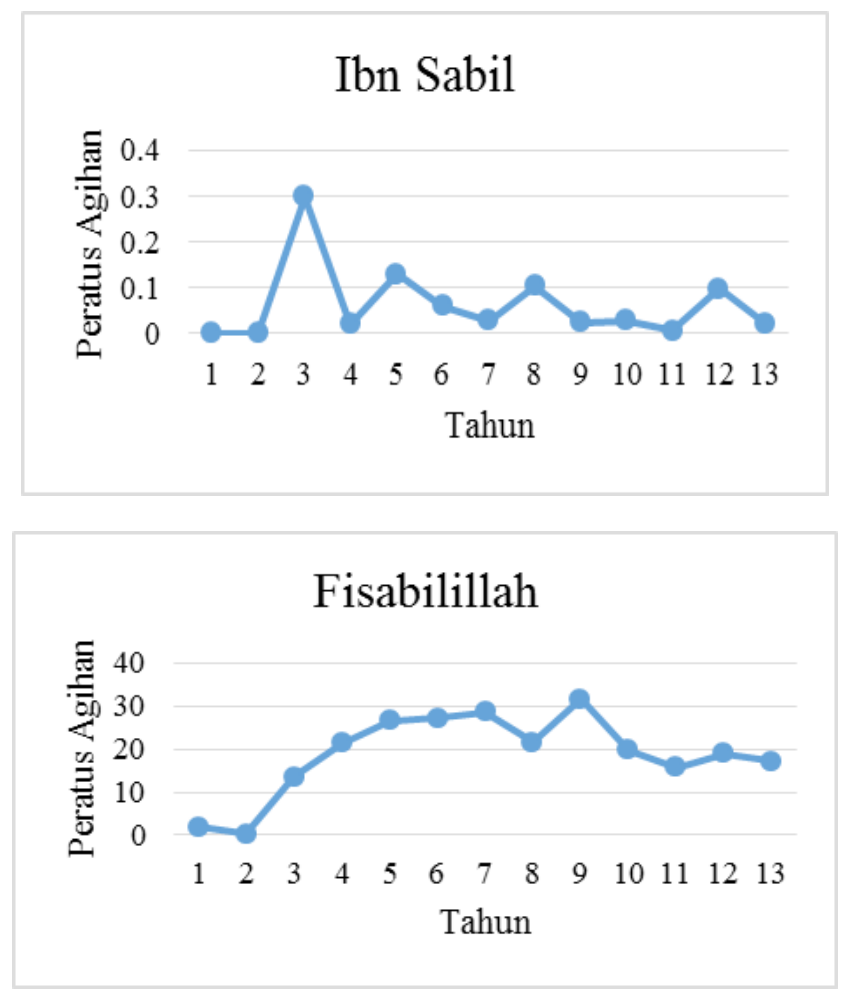

Sumber: Diolah daripada analisis Laporan Tahunan MUIS \& Laporan Zakat PZS-MUIS dari 2001 hingga 2013.

Hasil analisis mendapati corak agihan zakat bagi asnaf miskin mengalami penurunan yang konsisten sebelum dan setelah penubuhan PZS seperti yang ditunjukkan dalam Rajah 1. Hal ini mungkin disebabkan dasar PZS yang diselarikan dengan dasar dan fokus kerajaan negeri yang lebih menjurus kepada usaha menghapuskan kemiskinan tegar atau pun golongan fakir. Walau bagaimanapun, secara jangka panjang golongan miskin ini tidak dipandang sebelah mata malah tetap diberikan sokongan yang berterusan meliputi bantuan seperti perniagaan, bantuan pendidikan, perubatan dan sebagainya. Berdasarkan Jadual 8, hasil regresi menunjukkan bahawa dengan peningkatan 1 unit dalam tahun, maka peratus agihan zakat untuk asnaf miskin akan menurun sebanyak 4.16 peratus. Corak agihan dana zakat bagi asnaf miskin didapati menurun dan signifikan pada aras keertian 5 peratus. 
Berpandukan Rajah 1, didapati corak agihan zakat bagi asnaf amil sebelum penubuhan PZS pada 2007 adalah tidak konsisten dengan berlaku penurunan dan peningkatan dalam agihan zakat. Namun, setelah penubuhan PZS, corak agihan zakat bagi asnaf amil mengalami penurunan secara konsisten dari tahun ke tahun. Keadaan ini lebih didorong oleh usaha dan langkah penjimatan dalam pengurusan berdasarkan dasar gerak kerja dan imej korporat yang ingin ditonjolkan oleh PZS setelah diberikan nafas baharu pada 2007. Malah, penggunaan sistem elektronik dan terkini seperti skim potongan zakat melalui slip gaji dengan kerjasama PZS dan kebanyakan bank utama di Malaysia, bayaran zakat melalui sistem pesanan ringkas ( $\mathrm{sms}$ ) dan perbankan atas talian (online banking) memberikan kemudahan kepada pihak amil dan umat Islam selain dapat meningkatkan keefisienan dan menjimatkan kos pengurusan. Berdasarkan Jadual 8 pula, hasil regresi yang diperoleh menunjukkan bahawa dengan peningkatan 1 unit dalam tahun, maka peratus agihan zakat untuk asnaf amil akan menurun sebanyak 0.76 peratus. Corak agihan dana zakat bagi asnaf ini pula didapati menurun dan signifikan pada aras keertian 5 peratus.

Melalui Rajah 1 juga, hasil analisis kajian mendapati corak agihan zakat bagi asnaf mualaf secara keseluruhannya menunjukkan peningkatan sama ada sebelum dan selepas penubuhan PZS. Situasi ini adalah didorong oleh jumlah saudara baru yang sentiasa meningkat saban tahun di Sabah. Berdasarkan statistik di antara tahun 2000 sehingga 2009 sahaja, jumlah saudara baru yang dicatatkan adalah melebihi 18,000 orang dengan purata orang yang memeluk Islam di Sabah adalah sebanyak 1,800 orang setiap tahun seperti yang ditunjukkan dalam Jadual 9.

Jadual 9: Jumlah Pengislaman di Sabah dari tahun 2000 sehingga 2009

\begin{tabular}{cccccccccccc}
\hline Tahun & 2000 & 2001 & 2002 & 2003 & 2004 & 2005 & 2006 & 2007 & 2008 & 2009 & Jumlah \\
\hline $\begin{array}{c}\text { Bilangan } \\
\text { mualaf }\end{array}$ & 1,316 & 1,365 & 1,232 & 1,713 & 1,778 & 2,007 & 2,040 & 1,932 & 2,693 & 2,415 & 18,491 \\
\hline
\end{tabular}

Sumber: Jabatan Hal Ehwal Agama Islam Negeri Sabah.

Usaha dakwah pengislaman yang giat dilakukan pada sekitar tahun 70-an dan 80-an masih diteruskan dan dikekalkan dengan penambahbaikan sentiasa dilakukan. Ini termasuk penambahbaikan program bantuan kepada asnaf mualaf yang kebanyakannya diletakkan di bawah kategori yang sama dengan asnaf fakir dan miskin seperti bantuan umum, sara hidup, kos perubatan, bantuan pendidikan, perniagaan dan keusahawanan, serta pembinaan masjid atau surau dalam kawasan penempatan golongan mualaf ini. Ini menunjukkan PZS mengambil berat akan kebajikan asnaf mualaf dengan memberikan sokongan daripada peringkat asas sehingga ke peringkat pendidikan tinggi 
dan taraf kehidupan yang selesa yang semestinya memerlukan agihan yang banyak. Hasil regresi yang diperoleh berdasarkan Jadual 8 pula menunjukkan bahawa dengan peningkatan 1 unit dalam tahun, maka peratus agihan zakat untuk asnaf mualaf akan meningkat sebanyak 0.70 peratus. Corak agihan dana zakat bagi asnaf mualaf didapati meningkat dan signifikan pada aras keertian 5 peratus.

Berdasarkan Rajah 1, didapati corak agihan zakat bagi asnaf ibn sabīl sebelum penubuhan PZS adalah menurun walaupun tidak konsisten. Corak agihan zakat yang sama juga ditunjukkan setelah penubuhan PZS iaitu berlaku penurunan walaupun tidak konsisten. Hal ini mungkin disebabkan tindakan PZS yang telah mengecilkan skim bantuan kepada asnaf ini yang hanya menumpukan bantuan kewangan dan sara hidup, manakala bantuan selebihnya diletakkan di bawah kategori asnaf al-ghārimīn dan fì sabïlillah. Berdasarkan Jadual 8 juga, hasil regresi yang diperoleh menunjukkan bahawa dengan peningkatan 1 unit dalam tahun, maka peratus agihan zakat untuk asnaf ibn sabìl akan menurun sebanyak 0.004 peratus. Corak agihan dana zakat bagi asnaf ini didapati menurun dan tidak signifikan pada aras keertian 5 peratus.

Hasil analisis kajian mendapati corak agihan zakat bagi asnaf al-ghārimīn sebelum penubuhan PZS adalah meningkat seperti yang ditunjukkan melalui Rajah 1. Corak peningkatan juga diperoleh setelah penubuhan PZS dengan peningkatan yang mendadak berlaku pada tahun 2011. Situasi ini berlaku apabila PZS telah mempelbagaikan agihan zakat kepada asnaf al-ghārimīn yang berhutang, malah turut meliputi bantuan kewangan melibatkan kos perubatan, pembinaan rumah, bayaran utiliti dan sewa bagi penerima di bawah kategori asnaf ini. Malah, agihan melibatkan pembayaran hutang pendidikan bagi pelajar tahun akhir di institusi pengajian tinggi juga menyebabkan agihan zakat kepada golongan asnaf al-ghärimīn mengalami peningkatan. Hasil regresi yang diperoleh melalui Jadual 8 menunjukkan bahawa dengan peningkatan 1 unit dalam tahun, maka peratus agihan zakat untuk asnaf al-ghärimin akan meningkat sebanyak 0.14 peratus. Corak agihan dana zakat bagi asnaf alghārimīn didapati meningkat dan tidak signifikan pada aras keertian 5 peratus.

Berpandukan Rajah 1, didapati corak agihan zakat bagi asnaf fi sabïlillah sebelum penubuhan PZS adalah meningkat dari tahun ke tahun. Akan tetapi setelah penubuhan PZS pada tahun 2007, corak agihan zakat bagi asnaf ini mengalami penurunan walaupun tidak secara konsisten kerana terdapat peningkatan agihan pada tahun 2009 dan 2012. Hal ini disebabkan agihan zakat kepada asnaf $f i$ sabilillah berkait rapat dengan bantuan pelajaran dan pendidikan tajaan PZS dan jumlah pelajar yang ditaja. Ini termasuklah dermasiswa kepada pelajar dalam bidang perubatan, pengajian Islam, diploma 
dan persijilan, selain turut dipengaruhi penggajian tenaga pengajar di bawah skim zakat di sekolah-sekolah agama di seluruh Sabah. Bantuan bagi asnaf golongan ini juga meliputi pengurusan jenazah, bantuan bagi rumah anak yatim, dan badan bukan kerajaan (NGO) yang diberikan lebih berdasarkan kepada keperluan semasa. Melalui Jadual 8 pula, hasil regresi menunjukkan bahawa dengan peningkatan 1 unit dalam tahun, maka peratus agihan zakat untuk asnaf $f i$ sabïlillah akan meningkat sebanyak 1.06 peratus. Corak agihan dana zakat bagi asnaf $f i$ sabïlillah didapati meningkat walaupun kurang konsisten dan tidak signifikan pada aras keertian 5 peratus.

\section{IMPLIKASI DASAR DAN PERBINCANGAN}

Secara keseluruhan, prestasi pengurusan kewangan Majlis Ugama Islam Sabah (MUIS) berada pada tahap yang memberangsangkan, malah menunjukkan peningkatan walaupun nilai yang diperoleh seperti dalam dapatan kajian kurang konsisten. Prestasi pengurusan kewangan MUIS daripada aspek kecairan menunjukkan kebolehan dalam memenuhi tanggungan liabiliti semasa, dan dalam aspek nisbah keuntungan yang konsisten bagi kebanyakan tahun membolehkan pihak pengurusan merancang dengan lebih selesa pada masa hadapan. Namun, bagi aspek kesolvenan yang menjadi indikasi kepada kebolehan institusi dalam memenuhi obligasi kewangan bagi jangka panjang, nisbah yang diperoleh agak tidak sihat. Ini mungkin disebabkan oleh liabiliti jangka panjang melibatkan pinjaman daripada kerajaan negeri. Bagaimanapun, terdapat penurunan dalam jumlah liabiliti jangka panjang MUIS dari tahun ke tahun. Ini membuktikan bahawa MUIS sememangnya komited dalam memastikan kelancaran perjalanan kewangan agar ia tidak menjejaskan operasi dan aktiviti MUIS pada masa hadapan dan usaha yang telah dilakukan oleh MUIS dalam mengurangkan kadar pinjaman tersebut harus diberikan pujian. Menurut sumber perseorangan ${ }^{45}$ yang diperoleh, liabiliti jangka panjang tersebut adalah berkait rapat dengan kos pembinaan bangunan Wisma MUIS pada tahun 80-an. Apabila kesemua pinjaman dan hutang melibatkan liabiliti jangka panjang sedia ada diselesaikan sepenuhnya, maka MUIS secara langsung akan dapat menjana keuntungan secara jangka panjang pula melalui hasil daripada sewaan lot premis yang terdapat di bangunan Wisma MUIS itu sendiri dan ini adalah sesuatu yang sangat menggalakkan. Bagi aliran tunai aktiviti operasi ataupun lebihan pendapatan pula, secara keseluruhannya adalah pada tahap yang baik dan positif walaupun terdapat nisbah yang negatif yang perlu dititikberatkan dan diberikan perhatian sewajarnya agar tidak

45 Adnan Rosdin Mohd Arif (Timbalan Setiausaha MUIS merangkap Bendahari MUIS), dalam temu bual bersama beliau pada 10 Mac 2016. 
menjejaskan keseluruhan prestasi kewangan seperti pada tahun 2007 dan 2008 yang mungkin terjejas disebabkan krisis ekonomi melanda negara dan dunia pada ketika itu.

Walaupun Pusat Zakat Sabah yang ditubuhkan pada tahun 2007 menyerupai imej korporat, namun sebenarnya struktur pentadbirannya tidak diubah, malah tidak seperti institusi korporat lainnya. Ia masih diletakkan di bawah bidang kuasa dan salah satu bahagian pentadbiran MUIS. Dalam Seksyen 8 dan Seksyen 10 (Enakmen Zakat dan Fitrah 1993) menyatakan bahawa Bahagian Zakat dan Fitrah dianggotai oleh pegawai dan kakitangan daripada Perkhidmatan Awam Negeri yang diketuai oleh Ketua Penolong Setiausaha serta dibantu oleh beberapa Penolong Setiausaha yang menjawat jawatan dalam Perkhidmatan Awam Negeri. Malah setelah diteliti dengan lebih lanjut pada Bahagian II-Penubuhan dan Pentadbiran dalam enakmen tersebut didapati tiada perubahan struktur yang jelas menyamai pentadbiran korporat. ${ }^{46}$ Bagaimanapun, prestasi agihan zakat Pusat Zakat Sabah (PZSMUIS) setelah penubuhannya yang berimejkan korporat dan diberikan nafas baharu memperlihatkan peningkatan yang ketara dan sangat baik. Perkara ini memperlihatkan usaha memperkasa institusi zakat dengan mewujudkan budaya kerja bercirikan korporat membuahkan hasil. Ini terbukti apabila pada tahun 2007 nilai SKORLZ yang diperoleh adalah 0.00 iaitu nilai optimum 100 peratus. Hampir keseluruhan nilai skor kecekapan lebihan zakat dan skor kecekapan keutamaan asnaf adalah pada prestasi yang baik walaupun kurang konsisten antara keduanya. Hasil kajian ini juga selari dengan kajian terdahulu seperti bahawa nilai lebihan agihan zakat di bawah nilai 0.228 peratus bagi skor kecekapan lebihan zakat dan nilai skor di bawah 0.46 bagi skor kecekapan keutamaan asnaf adalah dianggap berprestasi baik. Ini menunjukkan PZSMUIS berjaya melaksanakan agihan zakat dengan adil mengikut keutamaan asnaf mazhab Imam Shāfi‘̄i.

Penekanan dalam agihan zakat kepada asnaf fakir dan miskin oleh PZSMUIS boleh dirumuskan bertepatan dengan agenda pembangunan yang dicetuskan oleh kerajaan negeri Sabah dalam membasmi kemiskinan dan meningkatkan kualiti kehidupan rakyat sebagai keutamaan. Justeru, adalah penting bagi MUIS dan PZS-MUIS dalam memastikan kedua-dua skor kecekapan dicapai secara serentak agar lebih konsisten bagi meningkatkan lagi kecekapan institusi zakat selari dengan agenda halatuju kerajaan negeri. Ini seterusnya boleh dicapai dengan penekanan terhadap aspek lebihan zakat dan agihan kepada asnaf mengikut keutamaan masing-masing. Kajian berpendapat aspek kutipan dan agihan zakat harus diperhalusi dengan lebih teliti terutama

46 Seksyen 8 dan 10, Enakmen Zakat dan Fitrah Negeri Sabah (No. 6 Tahun 1993). 
jurang tempoh waktu kutipan dan agihan dilaksanakan. Jurang waktu antara kutipan zakat yang kebiasaannya mencapai waktu puncak pada setiap bulan Ramadan dan penghujung tahun sebelumnya dengan aktiviti agihan zakat yang lazimnya dilakukan pada setiap suku pertama tahun semasa menyumbang kepada berlaku lebihan zakat semasa. Situasi berkenaan menyebabkan bantuan zakat tidak mencapai golongan sasaran secara menyeluruh. Justeru, jurang waktu yang agak panjang perlu dikurangkan agar jumlah kutipan dan agihan lebih tepat dan aktiviti kutipan dan agihan zakat lebih cekap dan sampai kepada golongan sasaran. Pendapatan zakat yang diperoleh pada tahun semasa perlu terus dibelanjakan dan diagihkan segera agar jumlah lebihan zakat dapat dikecilkan.

Pengumpulan data bagi setiap individu dan keluarga asnaf fakir dan miskin seperti bancian yang kemudiannya direkodkan dalam suatu sistem pangkalan data yang cekap diperlukan bagi merekodkan status semasa kedua-dua asnaf fakir dan miskin. Perkara ini juga selaras dengan Seksyen 9 Tanggungan Bahagian Zakat dan Fitrah, Enakmen Zakat dan Fitrah 1993 (No. 6 Tahun 1993) yang bertanggungjawab menjalankan urusan bancian penduduk Islam pada tiap-tiap tahun. ${ }^{47}$ Melalui bancian yang kemudian diolah kepada data tersebut, lebihan dana zakat yang terkumpul boleh disalurkan bagi membantu meningkatkan sosioekonomi asnaf fakir dan miskin dengan mewujudkan pelbagai kaedah bantuan secara lebih efisien. Pewujudan bantuan khusus seperti pekerjaan sampingan dan keusahawanan secara kecil-kecilan boleh dilaksanakan oleh PZS dengan menggunakan lebihan dana zakat tersebut. Hasil pemantauan dan pengawasan secara berterusan mahupun berkala oleh PZS terhadap status asnaf fakir dan miskin ini dan perkembangan mereka yang seterusnya direkodkan dalam sistem pangkalan data tadi amat penting dalam usaha agar kedua-duanya mampu keluar daripada kepompong kemiskinan dan berubah menjadi pembayar zakat kelak.

Sistem pangkalan data yang sama juga boleh diwujudkan terhadap asnaf mualaf dalam usaha untuk memudahkan pemantauan berterusan ke atas mereka. Sistem pangkalan data ini boleh menjadi perintis kepada institusi zakat yang lain kerana di Malaysia belum terdapat suatu sistem pangkalan data terhadap golongan mualaf secara menyeluruh dan sistematik. Kajian berpendapat dan menyarankan agar penetapan had tempoh status mualaf seperti kepada tempoh lima tahun atau tujuh tahun wajar dilaksanakan dan seterusnya diselaraskan di seluruh negara agar golongan mualaf ini dapat diberikan bantuan dengan lebih baik dari segi fizikal dan spiritual dalam jangka masa tertentu sehingga mereka benar-benar boleh berdikari dan tidak tersisih mahupun tercicir daripada

47 Seksyen 9, Enakmen Zakat dan Fitrah Negeri Sabah (No. 6 Tahun 1993). 
masyarakat. Ini secara tidak langsung akan membuatkan golongan asnaf ini berasa kebajikan mereka terjamin, terpelihara dan menghargai Islam sebagai jalan hidup pilihan mereka. Malah, agenda pendekatan dakwah Islamiah yang dilaksanakan oleh agensi kerajaan, Majlis Agama Islam dan badan-badan bukan kerajaan (NGO) Islam yang selama ini terbukti berhasil dan tidak siasia memerlukan penambahbaikan dan pendekatan yang lebih komprehensif dan sistematik sesuai dengan arus kemodenan. Idea ini boleh dilaksanakan dengan sokongan dan sumbangan pelbagai pihak terutamanya pihak berkuasa melibatkan Jabatan Pendaftaran Negara, institusi zakat, Jabatan Agama Islam Negeri dan masyarakat walaupun ia mungkin berdepan pelbagai kekangan dan cabaran terutamanya melibatkan kos yang tinggi dan keupayaan teknologi yang moden dan lengkap.

Bagi mencapai keseimbangan dan kesaksamaan dalam agihan zakat kepada kesemua lapan kategori asnaf, suatu penelitian dan penyemakan semula takrifan setiap asnaf perlu diberikan perhatian. Ini kerana terdapat golongan asnaf yang secara teorinya merupakan golongan yang sepatutnya diberikan agihan zakat namun tidak mendapat bahagian dalam agihan seperti asnaf al-riqāb. Walaupun PZS masih mengguna pakai takrifan asnaf al-riqāb berpandukan kitab-kitab dan ulama terdahulu, namun ia boleh diharmonikan dan disesuaikan dengan keadaan semasa pada hari ini. Ini secara langsung akan membolehkan dana zakat digunakan sepenuhnya secara maksimum bagi tujuan bantuan dan pembangunan setiap kategori asnaf serta dapat melibatkan lagi keseluruhan masyarakat yang layak menerima agihan zakat. Jika diteliti dengan lebih terperinci, terdapat beberapa negeri yang telah mengimplementasikan kaedah pentakrifan semula asnaf al-riqāb dan meletakkan beberapa skim bantuan zakat di bawah kategori asnaf al-riqāb seperti Negeri Sembilan yang telah meletakkan skim dermasiswa di bawah kategori asnaf al-riq $\bar{a} b .{ }^{48}$ Begitu juga dengan asnaf-asnaf yang lain, semakan takrifan sebenar di bawah mazhab Shāfi' $\overline{1}$ juga wajar dilakukan dalam usaha membolehkan keutamaan setiap kategori asnaf dalam agihan asnaf diperoleh dengan lebih tepat. Justeru, pelbagai pendekatan dan kaedah boleh diwujudkan ke arah kebaikan asnaf dan pembangunan mereka di samping mencapai keadilan dan keseimbangan dalam agihan zakat.

Usaha PZS-MUIS dalam meningkatkan jumlah kutipan zakat harus dipuji apabila terdapat peningkatan jumlah kutipan zakat yang diperoleh setiap tahun walaupun jumlahnya masih jauh berbanding kutipan negeri-negeri lain. Justeru, lebihan dana zakat boleh digunakan di bawah kategori fì sabïlillah

48 Rashidah Unos, Hairunnizam Wahid, Sanep Ahmad, 'Zakat: Analisis Perubahan Corak Agihan di Negeri Sembilan', 179-195. 
dengan mempelbagaikan program yang mampu meningkatkan syiar Islam di Sabah khususnya dalam meningkatkan kesedaran bagi menarik lebih ramai individu dan syarikat perniagaan untuk membayar zakat pendapatan, perniagaan, pertanian mahupun fitrah. PZS juga boleh meneroka peluang dalam melakukan transformasi kaedah informasi dan penyampaian maklumat agar ia lebih mencapai golongan sasaran. Ini termasuklah hebahan dan pengiklanan melalui media massa dan media sosial yang lebih dekat dengan masyarakat masa kini dalam menarik perhatian mereka mengenai kewajipan menunaikan zakat dan pengetahuan mengenai zakat. Melalui kategori asnaf fì sabïlillah juga pengagihan lebihan zakat dalam bentuk pelaburan jangka panjang seperti pendidikan dan kemahiran anak muda juga wajar diberi keutamaan kerana ia bukan sahaja membantu golongan pelajar dan anak muda mendapat bantuan kewangan semasa pengajian malah suatu pelaburan jangka panjang dalam bagi memenuhi keperluan membentuk anak muda profesional serta tenaga kerja mahir. Oleh itu, kajian berpendapat suatu dasar jangka panjang yang lebih bersifat holistik dan menepati sasaran harus dirangka melibatkan agihan zakat kepada asnaf fi sabïlillah agar tidak berlaku sebarang kebocoran dan keciciran melibatkan agihan zakat dan modal insan yang penting dalam melahirkan modal insan dan pelapis generasi akan datang yang berpendidikan dan berkebolehan yang mampu meningkatkan pembangunan negeri Sabah khususnya dan Malaysia umumnya.

Hubungan antara prestasi pengurusan kewangan oleh majlis agama dengan prestasi agihan zakat oleh institusi zakat yang signifikan telah dibuktikan melalui kajian ini. Kajian ini memfokuskan serta mengetengahkan kecekapan pengurusan kewangan dan agihan zakat oleh majlis agama dan institusi zakat berdasarkan laporan kewangan tahunan serta laporan zakat dan seterusnya melihat kesannya terhadap golongan asnaf. Melalui hasil regresi bagi peratusan agihan zakat, dapat diperhatikan bahawa hasil regresi telah menggambarkan terdapat hasil yang ketara bagi setiap kategori asnaf fakir, miskin, amil dan mualaf yang mana setiap daripada asnaf ini menunjukkan corak agihan yang signifikan dalam penerimaan agihan zakat. Ini selari dengan situasi sebenar kesan kecekapan pengurusan agihan zakat yang dilaksanakan oleh institusi zakat seperti yang dibincangkan dalam analisis corak agihan zakat kepada golongan asnaf, meskipun tidak dinafikan terdapat faktor lain yang juga boleh diambil kira dalam mempengaruhi situasi sebenar kesan kecekapan pengurusan agihan zakat seperti tahap ketersampaian agihan zakat kepada asnaf dan keadaan sosioekonomi golongan asnaf serta pengurangan kadar kemiskinan. Justeru, kajian lanjut boleh dilakukan dalam meneroka pelbagai pemboleh ubah dan faktor bagi mengetahui dengan lebih mendalam implikasi sebenar pungutan dan agihan zakat oleh sesebuah institusi zakat. 
Oleh itu, sangat penting bagi MUIS agar mengawal selia dan melakukan pemeriksaan yang berterusan terhadap tahap kesihatan kewangan agar pengurusan dan operasi jabatan menjadi lebih lancar, cekap dan efisien serta matlamat jabatan dapat dicapai dengan lebih efektif. Ini secara langsung turut melibatkan tanggungjawab MUIS melalui PZS-MUIS terutamanya dalam aspek mengutip dan mengagihkan zakat. Kajian juga selari dengan dapatan kajian terdahulu sepertinya ${ }^{49}$ bahawa prestasi kewangan dan pengagihan zakat akan menjadi lebih berkesan hasil kesinambungan pengurusan tersebut dilakukan oleh institusi yang sama. Hasil prestasi yang baik bagi MUIS dan PZS-MUIS mesti dikekalkan dan dipertingkatkan agar menambahkan lagi keyakinan pembayar zakat yang akan meningkatkan jumlah kutipan zakat pada masa hadapan dan meninggikan reputasi MUIS dan PZS-MUIS agar lebih dekat di hati masyarakat Islam keseluruhannya.

\section{KESIMPULAN}

Dalam mencapai kemiskinan sifar dan memacu pembangunan masyarakat menuju kemajuan negara menjelang tahun 2020, aspek kecekapan dan keberkesanan adalah sangat penting terutamanya bagi sektor awam yang merupakan perantara kerajaan dengan rakyat. Sebagai sebuah entiti awam, Majlis Agama Islam Negeri dan institusi zakat perlu memastikan kelancaran perjalanan tadbir urus kewangan agar dapat mengekalkan prestasi kecekapan yang baik. Prestasi institusi zakat dalam mengutip dan mengagihkan zakat haruslah diperkemas dan ditambah nilai kerana zakat berperanan dalam membasmi kemiskinan dan meningkatkan pembangunan masyarakat dan negara. Malah, prestasi yang cekap dan telus pasti meningkatkan keyakinan masyarakat untuk membayar zakat.

Kajian lanjut berbentuk lapangan juga perlu dijalankan terutama melibatkan tahap ketersampaian agihan zakat kepada golongan asnaf dan kajian terperinci yang menilai dinamik perubahan sosioekonomi dan taraf kehidupan asnaf kesan daripada kecekapan pengurusan agihan zakat. Ini kerana kesan sebenar agihan zakat terhadap asnaf harus dibuktikan agar imej dan peranan institusi zakat dapat dipertingkat dan asnaf pula mendapat manfaat agihan zakat mereka. MAIN dan institusi zakat juga perlu terus mengambil pendekatan proaktif serta inovatif dalam pengurusan operasi dan tindakan mereka dalam mewujudkan dan meningkatkan kesedaran masyarakat, badan korporat mahupun individu

49 Hairunnizam Wahid, Sanep Ahmad, Mohd Ali Mohd Nor \& Maryam Abd Rashid, 'Prestasi Kecekapan Pengurusan Kewangan dan Pengurusan Agihan Zakat: Perbandingan antara Majlis Agama Islam Negeri', 21-35. 
tentang tuntutan berzakat dalam agama, implikasi sosial dan ekonomi hasil daripada berzakat. Justeru, sebarang usaha dalam meningkatkan kredibiliti, prestasi dan kecekapan yang dilakukan oleh MUIS dan PZS-MUIS perlu diberikan sokongan penuh bagi kebaikan organisasi dan masyarakat Islam seluruhnya.

\section{RUJUKAN}

'Abd al-Raḥmān al-Jazirī, Kitāb al-Fiqh 'ala al-Madhāhib al-Arba 'ah (Beirūt: Dār al-Kutub al-'Ilmiyyah, 2003).

Ahmad Hidayat Buang \& Saidatul Badrul Mohd Said, 'Pentadbiran Zakat dan Kesedaran Masyarakat Islam Membayar Zakat di Daerah Kota Belud Sabah', Sains Humanika, 2/1 (2014): 125-134.

Andres-Alonso, de. P, Martin Cruz, N. \& Romero-Merino, M.E, 'The Governance of Nonprofit Organizations: Empirical Evidence from Nongovernmental Development Organizations in Spain,' Nonprofit and Voluntary Sector Quarterly, 35/4 (2006): 588-604.

Dayangku Aslinah Abd. Rahim, 'Zakat Potential in Sabah: Issues and Challenges' ( $5^{\text {th }}$ Islamic Economics System Conference (iECONS), Berjaya Times Square Hotel, Kuala Lumpur, 2013).

Eza Ellany Abdul Lateff, Mohd Rizal Palil \& Mohamat Sabri Hassan, 'Prestasi Kecekapan Agihan Kewangan dan Bukan Kewangan dalam Kalangan Institusi Zakat di Malaysia,' Jurnal Ekonomi Malaysia, 48/2 (2014): 5160.

Faiz Mat Isa, Hairunnizam Wahid \& Sanep Ahmad, 'Pengukuran Prestasi Menggunakan Nisbah Aliran Tunai dan Nisbah Tradisi: Perbandingan di Antara Majlis Agama Islam Selangor dan Majlis Agama Islam dan Adat Melayu Perak,' Proceeding International Conference Muamalat, Economic \& Islamic Finance (Bangi: Institut Latihan Islam Malaysia (ILIM), 2014), 310-325.

Fidlizan Muhammad, Mohd Yahya Mohd Hussin, Azila Abdul Razak \& Salwa Amirah Awang, 'Ketirisan Bayaran Zakat Terhadap Institusi Formal di Malaysia,' Sains Humanika, 5/1 (2015): 27-32.

Hairunnizam Wahid, Sanep Ahmad \& Radiah Abdul Kader, 'Pengagihan Zakat oleh Institusi Zakat di Malaysia: Mengapa Masyarakat Islam Tidak Berpuas Hati?’ Jurnal Syariah, 17/1 (2009): 89-112.

Hairunnizam Wahid, Sanep Ahmad \& Radiah Abdul Kader, 'Pengagihan Zakat oleh Institusi Zakat Kepada Lapan Asnaf: Kajian di Malaysia,' Jurnal Pengurusan JAWHAR, 4/1 (2010): 141-170. 
Hairunnizam Wahid, Sanep Ahmad, Mohd Ali Mohd Nor \& Maryam Abd Rashid, 'Prestasi Kecekapan Pengurusan Kewangan dan Pengurusan Agihan Zakat: Perbandingan antara Majlis Agama Islam Negeri', Isu Kontemporari Agihan Zakat di Malaysia, ed. Nor Aini Ali et al. (Kuala Lumpur: Majlis Agama Islam Wilayah Persekutuan (MAIWP), 2015): 21-35.

Ismail Ahmad \& Masturah Main, 'The Efficiency of Zakat Collection and Distribution: Evidence from Two Stage Analysis,' Journal of Economics and Development, 35/3 (2014): 133-170.

Laman Web Rasmi YAB Ketua Menteri Sabah, 'Halatuju Pembangunan dan Kemajuan Negeri Sabah atau "Halatuju",' http// www.sabah.gov.my/ $\mathrm{cm} /$ halatuju.php/, dicapai pada 20 Mac 2016.

Majlis Ugama Islam Sabah, Laporan Kewangan Tahunan Majlis Ugama Islam Sabah (Sabah: MUIS, 2000-2013).

Majlis Ugama Islam Sabah, Laporan Zakat Pusat Zakat Sabah (Sabah: MUIS, 2000-2013).

Maxwell Samuel Amuzu, 'Cash Flow Ratio As A Measure of Performance of Listed Companies in Emerging Economies: The Ghana Example' (St. Clements University, Turks and Caicos Islands Dissertation, 2014).

Md Hairi Md Hussain, Kamil Md. Idris \& Ram Al Jaffri Saad, 'Ketelusan di dalam Tadbir Urus Institusi Zakat', Prosiding Seminar Isu-Isu Kontemporari Zakat di Malaysia (Langkawi: Pusat Islam UUM, 2012), 63-74.

Mohamad Uda Kasim, Zakat: Teori, Kutipan dan Agihan (Kuala Lumpur: Utusan Publications \& Distributors Sdn Bhd, 2013).

Mohd Yahya Mohd Hussin, Fidlizan Muhammad \& Mohamad Ali Roshidi Ahmad, 'Kepatuhan Membayar Zakat: Analisis Kutipan dan Ketirisan Zakat Fitrah di Selangor,' Jurnal Syariah, 21/2 (2013): 191-206.

Monir \& Wahyu, 'Public Sector Financial Management Reform: A Case Study of Local Government Agencies in Indonesia,' Australasian Accounting, Business and Finance Journal, 7/4 (2013): 97-117.

Pusat Zakat Sabah, 'Sejarah Penubuhan Pusat Zakat Sabah,' laman sesawang Pusat Zakat Sabah, www.zakat.sabah.gov.my, dicapai pada 25 Mac 2016.

Ram Al Jaffri Saad, Norazita Marina Abdul Aziz \& Norfaiezah Sawandi, 'Islamic Accountability Framework in the Zakat Funds Management' Procedia-Social and Behavioral Sciences, 164 (2014): 508-515. 
Rashidah Unos, Hairunnizam Wahid, Sanep Ahmad, 'Zakat: Analisis Perubahan Corak Agihan di Negeri Sembilan', Isu Kontemporari Agihan Zakat di Malaysia, ed. Nor Aini Ali et al. (Kuala Lumpur: Majlis Agama Islam Wilayah Persekutuan (MAIWP), 2015): 179-195.

Robin Hill, 'What Sample Size is Enough in Internet Survey Research,' Interpersonal Computing \& Technology, 6/3-4 (1998).

Teh Suhaila Tajuddin, Aza Shahnaz Azman \& Noraini Shamsuddin, 'Impak Agihan Zakat Terhadap Kualiti Asnaf di Selangor,' Proceeding $2^{\text {nd }}$ International Conference on Economics \& Banking (Bangi: Faculty of Management \& Muamalah, KUIS, 2016), 226-237.

\section{Statut}

Enakmen Majlis Ugama Islam Negeri Sabah (No.5 Tahun 2004).

Enakmen Zakat dan Fitrah Negeri Sabah (No. 6 Tahun 1993).

\section{Temu bual}

Adnan Rosdin Mohd Arif (Timbalan Setiausaha MUIS merangkap Bendahari MUIS), dalam temu bual bersama beliau pada 10 Mac 2016. 